\title{
The serendipitous origin of chordate secretin peptide family members
}

João CR Cardoso*, Florbela A Vieira, Ana S Gomes and Deborah M Power

\begin{abstract}
Background: The secretin family is a pleotropic group of brain-gut peptides with affinity for class $2 \mathrm{G}$-protein coupled receptors (secretin family GPCRs) proposed to have emerged early in the metazoan radiation via gene or genome duplications. In human, 10 members exist and sequence and functional homologues and ligand-receptor pairs have been characterised in representatives of most vertebrate classes. Secretin-like family GPCR homologues have also been isolated in non-vertebrate genomes however their corresponding ligands have not been convincingly identified and their evolution remains enigmatic.

Results: In silico sequence comparisons failed to retrieve a non-vertebrate (porifera, cnidaria, protostome and early deuterostome) secretin family homologue. In contrast, secretin family members were identified in lamprey, several teleosts and tetrapods and comparative studies revealed that sequence and structure is in general maintained. Sequence comparisons and phylogenetic analysis revealed that PACAP, VIP and GCG are the most highly conserved members and two major peptide subfamilies exist; i) PACAP-like which includes PACAP, PRP, VIP, PH, GHRH, SCT and ii) GCG-like which includes GCG, GLP1, GLP2 and GIP. Conserved regions flanking secretin family members were established by comparative analysis of the Takifugu, Xenopus, chicken and human genomes and gene homologues were identified in nematode, Drosophila and Ciona genomes but no gene linkage occurred. However, in Drosophila and nematode genes which flank vertebrate secretin family members were identified in the same chromosome.

Conclusions: Receptors of the secretin-like family GPCRs are present in protostomes but no sequence homologues of the vertebrate cognate ligands have been identified. It has not been possible to determine when the ligands evolved but it seems likely that it was after the protostome-deuterostome divergence from an exon that was part of an existing gene or gene fragment by rounds of gene/genome duplication. The duplicate exon under different evolutionary pressures originated the chordate PACAP-like and GCG-like subfamily groups. This event occurred after the emergence of the metazoan secretin GPCRs and led to the establishment of novel peptide-receptor interactions that contributed to the generation of novel physiological functions in the chordate lineage.
\end{abstract}

\section{Background}

The evolution of the secretin family of brain-gut peptides remains enigmatic despite being some of the first endocrine factors ever identified. For example, in 1902 the ground breaking experiments of Bayliss and Starling with dog intestinal extracts set off the search for the active principal and, by 1961, secretin (SCT) had been isolated and sequenced [1]. Currently, 10 peptides belonging to the secretin family have been isolated in humans and include; SCT, vasoactive intestinal peptide (VIP), pitu-

* Correspondence: jccardo@ualg.pt

${ }^{1}$ Centre of Marine Sciences (CCMAR), Universidade do Algarve, Campus de Gambelas, 8005-139 Faro, Portugal

Full list of author information is available at the end of the article itary adenylate cyclase-activating polypeptide (PACAP), peptide histidine methionine (PHM), PACAP-related peptide (PRP), growth hormone-releasing hormone (GHRH), glucagon (GCG), glucagon-like peptide (GLP 1 and 2) and glucose-dependent insulinotropic peptide (GIP) [2-4]. Members of the secretin family share significant structural and conformational homology and their key metabolic and developmental functions in human make them of considerable pharmacological interest. Members of class 2 G-protein coupled receptors (a.k.a family B GPCRs), bind and are activated by the secretin family members (family B1 members or secretin family GPCRs) and specific peptide-receptor pairs have been identified in representatives of different vertebrate 
classes. Class 2 GPCRs is a larger family of receptors and also includes members of the metazoan adhesion (B2) and insect methuselah (B3) families and secretin family GPCRs (B1) are proposed to descend from the adhesion receptors prior to protostome-deuterostome divergence $[5,6]$.

In protostomes (nematodes, arthropods, annelids and platyhelminthes) and early deuterostomes such as Ciona and amphioxus, immunohistochemical (IHC) approaches using antisera raised against various mammalian secretin family members suggest they possess similar peptides to vertebrates (Table 1). PACAP-like genes (pacap1 and pacap2) have only been reported in the tunicate, Chelyosoma productum [7] and partial mRNAs (114bp) corresponding to the highly conserved PACAP coding exon [8] have been isolated in Hydra magnipapillata and several protostomes and deposited in public databases [9]. The existing data has been taken to indicate that an ancestral secretin family gene was probably present prior to the deuterostome-protostome divergence and most likely resembled the vertebrate PACAP precursor [2,8,10-12]. Paradoxically, in protostomes with fully sequenced genomes and extensive molecular resources (Figure 1, Additional file 1), genes encoding ligands homologous to members of the vertebrate secretin family have not been reported. In contrast, secretin-like family GPCR encoding genes which share similar sequence, structure and conserved gene environment with the vertebrate members have been identified, making ligand-receptor evolution an interesting enigma [13-16].

The present study focuses on secretin family ligands and complements previous studies aimed at identifying and characterising the evolution of family 2 GPCRs $[5,6,8,14,17]$. A comparative approach which takes advantage of the wealth of information currently available (genome, ESTs, peptide) for porifera, cnidaria, protostomes, early deuterostomes and vertebrates (Figure 1), is undertaken to re-evaluate the origin of the secretin family in metazoa. The sequence, gene structure and gene environment of secretin family members in vertebrates with sequenced genomes was characterised and used to search for homologue peptides, genes or genome regions in nonvertebrates.

\section{Results}

\section{Vertebrate secretin family members}

Sequence database searches using the nucleotide and mature peptide sequences of human and zebrafish secretin family members, readily identified homologues in lamprey, teleost and tetrapod (Хеnopus, lizard, chicken) genomes. This is due to the high sequence conservation of the mature peptide region between the vertebrate members which facilitates their identification (Table 2) (see reviews $[2,4,8,18,19])$.

\section{The tetrapod members}

In humans, 10 peptides encoded by six genes have been isolated. In Aves, homologues of the mammalian members have been identified and peptides and corresponding transcripts were isolated in duck (Anas platyrhynchos), chicken (Gallus gallus) and turkey (Meleagris gallopavo) [20-27]. In silico analysis of the chicken genome identified six genes encoding secretin family members which share similar organisation to the human homologues and comparative analysis revealed they correspond to the peptides and nucleotide precursors previously described (Table 1 and Table 2). Searches in the reptile and amphibia genomes identified homologues for all human members with the exception of SCT and it remains to be established if the failure is due to the incomplete nature of their genome assemblies or to the absence of this gene. In reptiles, few members of this family have been reported to date. A VIP and GCG peptides were isolated from the Alligator mississippiensis, the nucleotide precursor of the latter peptide reported from the Heloderma suspectum [28-30] and a PRP/PACAP mRNA was recently characterised from the Italian wall lizard Podarcis sicula [31,32]. Sequence database searches on the lizard Anolis carolinensis genome identified for the first time the genes encoding the reptile PHI/VIP (ENSACAG00000005619), PRP/ PACAP (ENSACAG00000008729), GHRH (ENSACA G00000011836), GCG/GLP (ENSACAG00000014182) and GIP (ENSACAG00000006291) (Table 2). The predicted gene organisation suggests the coding exons for the mature peptides share identical structure with other metazoan genes and to date the exon encoding the lizard GLP2 remains to be identified.

Homologues of human secretin members have previously been reported in amphibians. VIP and PACAP and were isolated in Rana ridibunda [33,34]; GCG from Rana catesbeiana [35] and in Xenopus laevis single transcripts for PRP/PACAP [36], PHI/VIP, GHRH [37], GCG/GLP [38] and GIP [27] have been described. The genome of Xenopus tropicalis contains secretin family homologues which share high sequence conservation with the tetrapod genes (Table 2), but one difference was the presence of three GLP1 exons (GLP1a, b and c) within the GCG/ GLP gene structure as a result of a species-specific exon duplication.

\section{The fish members}

Peptides, transcripts and genes of the secretin family have also been isolated from the most diverse vertebrate clade, the teleosts. VIP was isolated from cod (Gadus morhua) $[39,40]$ and goldfish (Carassius auratus) [41], PACAP from the Japanese stargazer (Uranoscopus japonicus) [42] and GCG from the channel catfish (Ictalurus punctatus) $[43,44]$ (Table 1). The identification of two transcripts for PHI/VIP in goldfish Carassius auratus [45] and zebrafish 
Table 1: Molecular and expression data available for the secretin members in metazoa.

\begin{tabular}{|c|c|c|c|c|c|c|c|c|}
\hline & Species & $\begin{array}{c}\text { PRP/ } \\
\text { PACAP }\end{array}$ & $\mathrm{PH} / \mathrm{VIP}$ & GHRH & GCG/GLP & GIP & SCT & References \\
\hline \multicolumn{9}{|l|}{ DEUTEROSTOMES } \\
\hline \multicolumn{9}{|l|}{ VERTEBRATES } \\
\hline Mammal & Homo sapiens & $\mathbf{N}$ & $\mathbf{N}, \mathbf{P}$ & $N, P$ & $\mathbf{N}, \mathbf{P}$ & $\mathbf{N}, \mathbf{P}$ & $\mathbf{N}, \mathbf{P}$ & [100-109] \\
\hline \multirow[t]{3}{*}{ Ave } & Anas platyrhynchos & $\mathbf{N}$ & $\mathbf{N}$ & $\mathbf{N}$ & $\mathbf{P}$ & & & {$[9,21,22]$} \\
\hline & Gallus gallus & $\mathrm{N}, \mathrm{P}$ & $\mathrm{N}, \mathrm{P}$ & $\mathbf{N}$ & $\mathbf{N}, \mathbf{P}$ & $\mathbf{N}$ & $\mathbf{P}$ & {$[24-27,35,110-112]$} \\
\hline & Meleagris gallopavo & & $\mathbf{N}$ & & $\mathbf{N}$ & & & {$[23,113]$} \\
\hline \multirow[t]{3}{*}{ Reptile } & Alligator mississippiensis & & $\mathbf{P}$ & & $\mathbf{P}$ & & & {$[28,29]$} \\
\hline & Heloderma suspectum & & & & $\mathbf{N}$ & & & {$[30]$} \\
\hline & Podarcis sicula & $\mathbf{N}$ & & & & & & {$[31]$} \\
\hline \multirow[t]{4}{*}{ Amphibia } & Rana catesbeiana & & & & $\mathbf{P}$ & & & [114] \\
\hline & Rana ridibunda & $\mathbf{N}, \mathbf{P}$ & $\mathbf{P}$ & & & & & {$[33,34]$} \\
\hline & Xenopus laevis & $\mathbf{N}$ & $\mathbf{N}$ & $\mathbf{N}$ & $\mathbf{N}$ & $\mathbf{N}$ & & {$[9,27,36-38]$} \\
\hline & Xenopus tropicalis & & & & $\mathbf{N}$ & $\mathbf{N}$ & & {$[9,27]$} \\
\hline \multirow[t]{8}{*}{ Teleost } & Carassius auratus & & $\mathrm{N}, \mathrm{P}$ & $\mathbf{N}$ & $\mathbf{N}$ & & & {$[37,41,45,115]$} \\
\hline & Clarias macrocephalus & $\mathbf{N}$ & & & $\mathbf{N}$ & & & {$[9,116]$} \\
\hline & Danio rerio & $\mathbf{N}$ & $\mathbf{N}$ & $\mathbf{N}$ & $\mathbf{N}$ & $\mathbf{N}$ & & {$[9,27,37,47,83,117,118]$} \\
\hline & Gadus morhua & $\mathbf{N}$ & $\mathbf{P}$ & & & & & {$[39,40]$} \\
\hline & Ictalurus punctatus & $\mathbf{N}$ & & & $\mathbf{N}, \mathbf{P}$ & & & {$[9,43,44]$} \\
\hline & Oncorhynchus nerka & $\mathbf{N}$ & & & & & & [119] \\
\hline & Takifugu rubripes & $\mathbf{N}$ & $\mathbf{N}$ & & & & & [8] \\
\hline & Uranoscopus japonicus & $\mathbf{P}$ & & & & & & {$[42]$} \\
\hline \multirow[t]{3}{*}{ Chondrichthyes } & Torpedo marmota & $\mathrm{N}, \mathrm{IHC}$ & & & & & & [120] \\
\hline & Dasyatis akajei & IHC & & & & & & [121] \\
\hline & Callorhynchus milii & & & & $\mathbf{P}$ & & & [122] \\
\hline \multirow[t]{3}{*}{ Agnatha } & Lampetra fluviatilis & & & & $\mathbf{P}$ & & & [123] \\
\hline & Lampetra japonica & $\mathbf{N}$ & & & & & & [9] \\
\hline & Petromyzon marinus & & & & $\mathrm{N}, \mathrm{P}$ & & & {$[52,124]$} \\
\hline \multirow[t]{4}{*}{ UROCHORDATES } & Chelyosoma productum & $\mathbf{N}$, IS & & & & & & [7] \\
\hline & Ciona intestinalis & & IHC & & & & IHC & [125-127] \\
\hline & Halocynthia roretzi & $\mathbf{N}^{*}$ & & & & & & [9] \\
\hline & Styela plicata & & IHC & & IHC & & IHC & {$[125,127-129]$} \\
\hline CEPHALOCHORDATES & $\begin{array}{l}\text { Branchiostomata } \\
\text { lanceolatum }\end{array}$ & & IHC & & IHC & & IHC & {$[127,130,131]$} \\
\hline \multicolumn{9}{|l|}{ PROTOSTOMES } \\
\hline \multirow[t]{3}{*}{ NEMATODES } & Ascaridia galli & & IHC & & & & & [132] \\
\hline & Nematodirus battus & & IHC & & & & & [132] \\
\hline & $\begin{array}{l}\text { Nippostrongylus } \\
\text { brasiliensis }\end{array}$ & & IHC & & & & & [132] \\
\hline \multirow[t]{5}{*}{ ARTHROPODS } & Aeschna cyanea & & IHC & & & & & {$[133,134]$} \\
\hline & Eriocheir japonica & $\mathbf{N}^{*}$ & & & & & & [9] \\
\hline & Eristalis aeneus & & & & IHC & & IHC & [135] \\
\hline & Manduca sexta & & IHC & & IHC & IHC & IHC & [136] \\
\hline & Periplaneta americana & $\mathbf{N}^{*}$ & IHC & & & & & {$[9,10,131,137,138]$} \\
\hline ANNELIDS & Hirudo medicinalis & & IHC & & & & & {$[131,139]$} \\
\hline
\end{tabular}


Table 1: Molecular and expression data available for the secretin members in metazoa. (Continued)

\begin{tabular}{|c|c|c|c|c|c|c|}
\hline & Lumbricus terrestris & IHC & IHC & & & {$[131,140,141]$} \\
\hline & Nereis diversicolor & & IHC & & & {$[131,142]$} \\
\hline & Helix pomatia & & IHC & & & [143] \\
\hline \multirow[t]{4}{*}{ MOLLUSCS } & $\begin{array}{l}\text { Mytilus } \\
\text { galloprovencialis }\end{array}$ & & IHC & & & [144] \\
\hline & Planorbarius corneus & & IHC & IHC & IHC & [145] \\
\hline & Sepioteuthis lessoniana & $\mathbf{N}^{*}$ & & & & [9] \\
\hline & Viviparus ater & & IHC & IHC & IHC & [146] \\
\hline \multirow[t]{2}{*}{ PLATYHELMINTHES } & Dugesia japonica & $\mathbf{N}^{*}$ & & & & [9] \\
\hline & Schistosoma mansoni & & IHC & & & [147] \\
\hline CNIDARIA & Hydra magnipapillata & $\mathbf{N}^{*}$ & & & & [9] \\
\hline
\end{tabular}

Nucleotide (N), Protein (P), Immunohistochemical (IHC) and in situ (IS) $\mathrm{N}^{*}$ non-vertebrate nucleotide sequences deposited in NCBI

(Danio rerio) (PHI/VIP $a$, EU031789 and PHI/VIP $b$, EU031790) and of two PRP/PACAP (PRP/PACAP $a$, NM_152885 and PRP/PACAP $b$, AF329633) [46,47] and GCG/GLP precursors in zebrafish [48] suggests they are duplicates in fish and this has been confirmed by the identification of two PRP/PACAP and GCG/GLP genes in Takifugu (ENSTRUG00000003782 and ENSTRU G00000010059; ENSTRUG00000008721 and ENSTRU G00000004633, respectively) and Tetraodon (ENSTNI G00000017117 and ENSTNIG00000018649; ENSTNIG 00000013278 and ENSTNIG00000000614, respectively) genomes (Table 2) [8]. The greater number of secretin family genes identified in fish relative to tetrapods is most likely to be a result of the proposed teleost specific genome duplication and the absence of GIP and GHRH gene duplicates suggests they were probably deleted [4951]. In common with Xenopus, no homologue of human SCT has been identified in fish genomes.

In the sea lamprey (Petromyzon marinus), a primitive vertebrate of the Agnatha clade, two homologues of human proglucagon (GCG/GLP) were characterised in the genome assembly Contig 31522 (GENSCAN 00000079364) and Contig 32128 which correspond to the previously reported proglucagon I (AF159707) and proglucagon II (AF159708) transcripts, respectively [52]. In the present study, searches of the partially sequenced lamprey genome retrieved putative PRP/PACAP (GENSCAN00000120210 on Contig3575.2) and PHI/VIP genes (shared between GENSCAN00000109335 and GENSCAN00000056150 localised on Contig20045.2 and Contig20045.3, respectively). However, GHRH, SCT and GIP were not identified possibly due to the present incomplete nature of its genome assembly.

\section{Sequence and gene structure comparison}

Sequence comparisons reveal that members of the secretin family are highly conserved and this also applies to their secondary structure which consists of a random Nterminal structure and a C-terminal alpha-helix [53,54]. The lamprey, teleost, Xenopus, reptile and chicken members are in general $50 \%$ identical in amino acid sequence with the human homologues (Figure 2) and two main peptide subfamilies, which share in general a maximum of $60 \%$ sequence similarity between their members were identified; i) PACAP-like subfamily which includes 6 peptide groups (PACAP, PRP, VIP, PHI, GHRH and SCT) and ii) GCG-like subfamily which contains 4 peptide groups (GCG, GLP1, GLP2 and GIP). Highest sequence conservation from lamprey to human ( $>70 \%$ sequence identity) occurs within PACAP, VIP and GCG peptide groups which contrasts with PRP and GLP2 that are the most divergent and Takifugu PRP $b$ and GLP2 predicted peptides are only $33 \%$ and $37 \%$ identical with the human homologues.

Consensus amino acids for peptide subfamilies were deduced and the overall conservation characterised. With few exceptions, 7 amino acid residues $\mathrm{H}^{1}, \mathrm{D}^{3}, \mathrm{~F}^{6}, \mathrm{~T}^{7}, \mathrm{Y}^{10}$, $\mathrm{Q}^{16}$ and $\mathrm{L}^{23}$ are the most abundant across the PACAP-like subfamily (Figure 2). The residues $\mathrm{H}^{1}, \mathrm{D}^{3}$ and $\mathrm{L}^{23}$ are present in all peptide groups with occasional exceptions in some taxa. However, the motif $\mathrm{F}^{6} \mathrm{~T}^{7}$ is absent from the vertebrate $\mathrm{PRP}$ sequences and is only present in tunicate $\mathrm{PRP}$ and the residue $\mathrm{Q}^{16}$ is absent from the SCT mature peptide and $\mathrm{Y}^{10}$ is only present in the chicken SCT homologue. This suggests that specific modifications occurred within the conserved core domain of the PACAP-like subfamily members and their functional significance remains to be explored. A similar comparison of the vertebrate GCG-like subfamily indicates that 15 amino acid residues $\mathrm{H}^{1}, \mathrm{~A}^{2}, \mathrm{G}^{4}, \mathrm{~T}^{5}, \mathrm{~F}^{6}, \mathrm{~S}^{8}, \mathrm{D}^{9}, \mathrm{~S}^{11}, \mathrm{~L}^{14}, \mathrm{~A}^{19}, \mathrm{~K}^{20}, \mathrm{~F}^{22}$, $\mathrm{V}^{23}, \mathrm{~W}^{25}$, and $\mathrm{L}^{26}$ are generally maintained across the 4 peptide groups. Even if taxa variability is taken into consideration, the residues $\mathrm{G}^{4}, \mathrm{~F}^{6}$ and $\mathrm{F}^{22}$ and the motifs $\mathrm{S}^{8} \mathrm{D}^{9}$ 


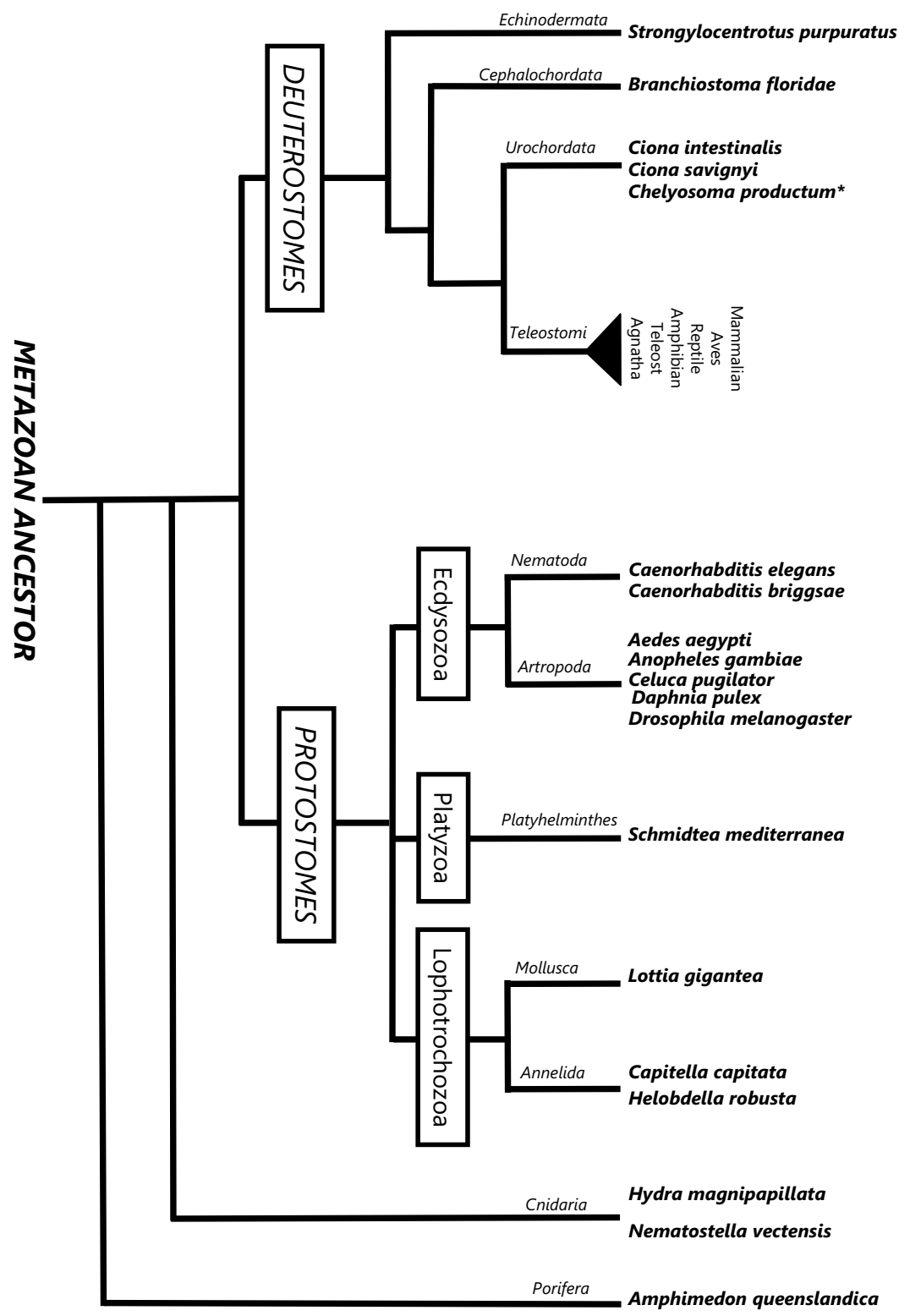

Figure 1 Phylogenetic position of the non-vertebrate genomes analysed. Simplified phylogeny of the metazoan evolution indicating the relative position of the early metazoa (Porifera and Cnidaria), protostome (Nematoda, Arthropoda, Platyhelminthes, Mollusca, Annelida) and early deuterostome (Echinodermata, Cephalochordata and Urochordata) genomes analysed (adapted from [96-98]). The tunicate Chelyosoma productum is also represented ${ }^{*}$ ) since it is the only invertebrate in which secretin family members have been isolated [7].

and $\mathrm{W}^{25} \mathrm{~L}^{26}$ are in general maintained (Figure 2). Peptide specific variations include for GIP, $\mathrm{H}^{1}$ which is replaced by $\mathrm{Y}, \mathrm{L}^{14}$ which is replaced by $\mathrm{M}$ or $\mathrm{V}$ (with exception of lizard) and $\mathrm{A}^{19}$ which is replaced by $\mathrm{K}$ or $\mathrm{Q}$. In the GCG mature peptide sequence $\mathrm{A}^{2}$ is replaced by $\mathrm{S}$ and in GLP2 with the exception of chicken and Takifugu $\mathrm{T}^{5}$ is replaced by $\mathrm{S}$. Comparison of the metazoan PACAP-like and GCG-like subfamily consensus sequence revealed they overlap for the residues $\mathrm{H}^{1}$ and $\mathrm{F}^{6}$ which are key amino acids in secretin GPCR binding affinity $[19,53,55,56]$. This suggests that, after exon/chromosome duplication of their common ancestor exon, distinct evolutionary pressures within each subfamily occurred.

The chordate PACAP shares in general $92 \%$ of amino acid sequence similarity with VIP and these two peptides are the most conserved members (Figure 3). In contrast, 
Table 2: Accession numbers (ENSEMBL) of non-mammalian secretin members.

\begin{tabular}{|c|c|c|c|c|c|c|}
\hline & PRP/PACAP & PH/VIP & GHRH & GCG/GLP & GIP & SCT \\
\hline $\begin{array}{c}\text { Chicken } \\
\text { (Gallus gallus) }\end{array}$ & $\begin{array}{c}\text { ENSGALG0000 } \\
0014858\end{array}$ & $\begin{array}{c}\text { ENSGALG0000 } \\
0013604\end{array}$ & $\begin{array}{c}\text { ENSGALG0000 } \\
0003842\end{array}$ & $\begin{array}{c}\text { ENSGALG0000 } \\
0011104\end{array}$ & $\begin{array}{c}\text { ENSGALG0000 } \\
0001299\end{array}$ & $\begin{array}{c}\text { ENSGALG0000 } \\
0005081\end{array}$ \\
\hline $\begin{array}{c}\text { Lizard } \\
\text { (Anolis } \\
\text { carolinensis) }\end{array}$ & $\begin{array}{c}\text { ENSACAG000 } \\
00008729\end{array}$ & $\begin{array}{c}\text { ENSACAG000 } \\
00005619\end{array}$ & $\begin{array}{c}\text { ENSACAG000 } \\
00011836\end{array}$ & $\begin{array}{c}\text { ENSACAG000 } \\
00014182\end{array}$ & $\begin{array}{c}\text { ENSACAG000 } \\
00006291\end{array}$ & ---- \\
\hline $\begin{array}{l}\text { Xenopus } \\
\text { (Xenopus } \\
\text { tropicalis) }\end{array}$ & $\begin{array}{c}\text { ENSXETG0000 } \\
0019179\end{array}$ & $\begin{array}{c}\text { ENSXETG0000 } \\
0027906\end{array}$ & $\begin{array}{c}\text { ENSXETESTG0 } \\
0000008409\end{array}$ & $\begin{array}{c}\text { ENSXETG0000 } \\
0013178\end{array}$ & Scaffold_334 & --- \\
\hline $\begin{array}{c}\text { Takifugu } \\
\text { (Takifugu } \\
\text { rubripes) }\end{array}$ & $\begin{array}{c}\text { ENSTRUG0000 } \\
0003782 \\
\text { ENSTRUG0000 } \\
0010059\end{array}$ & $\begin{array}{c}\text { ENSTRUG0000 } \\
0001139\end{array}$ & ---- & $\begin{array}{c}\text { ENSTRUG0000 } \\
0008721 \\
\text { ENSTRUG0000 } \\
0004633\end{array}$ & ---- & ---- \\
\hline $\begin{array}{l}\text { Tetraodon } \\
\text { (Tetraodon } \\
\text { nigroviridis) }\end{array}$ & $\begin{array}{c}\text { ENSTNIG0000 } \\
0017117 \\
\text { ENSTNIG0000 } \\
0018649\end{array}$ & $\begin{array}{c}\text { ENSTNIG0000 } \\
0007449\end{array}$ & $\begin{array}{c}\text { ENSTNIG0000 } \\
0007343\end{array}$ & $\begin{array}{c}\text { ENSTNIG0000 } \\
0013278 \\
\text { ENSTNIG0000 } \\
0000614\end{array}$ & --- & ---- \\
\hline $\begin{array}{c}\text { Zebrafish } \\
\text { (Danio rerio) }\end{array}$ & $\begin{array}{c}\text { ENSDARG000 } \\
00004015 \\
\text { ENSDARG000 } \\
00027740\end{array}$ & $\begin{array}{c}\text { ENSDARG000 } \\
00079443 \\
\text { ENSDARG000 } \\
00078247\end{array}$ & $\begin{array}{c}\text { ENSDARG000 } \\
00069481\end{array}$ & $\begin{array}{c}\text { ENSDARG000 } \\
00042999 / \\
\text { ENSDARG000 } \\
00079296 \\
\text { ENSDARG000 } \\
00040907\end{array}$ & $\begin{array}{c}\text { ENSDARG000 } \\
00071306\end{array}$ & ---- \\
\hline $\begin{array}{c}\text { Stickleback } \\
\text { (Gasterosteus } \\
\text { aculeatus) }\end{array}$ & $\begin{array}{c}\text { ENSGACG000 } \\
00017084 \\
\text { ENSGACG000 } \\
00004163\end{array}$ & $\begin{array}{c}\text { ENSGACG000 } \\
00001298\end{array}$ & $\begin{array}{c}\text { ENSGACG000 } \\
00001298\end{array}$ & $\begin{array}{c}\text { ENSGACG000 } \\
00013877 \\
\text { ENSGACG000 } \\
00005606\end{array}$ & ---- & ---- \\
\hline $\begin{array}{c}\text { Medaka } \\
\text { (Oryzias } \\
\text { latipes) }\end{array}$ & $\begin{array}{c}\text { ENSORLG0000 } \\
0017872 \\
\text { ENSORLG0000 } \\
0011205\end{array}$ & $\begin{array}{c}\text { ENSORLG0000 } \\
0003905\end{array}$ & ---- & $\begin{array}{c}\text { ENSORLG0000 } \\
0002782 \\
\text { ENSORLG0000 } \\
0016891\end{array}$ & ---- & ---- \\
\hline $\begin{array}{c}\text { Lamprey } \\
\text { (Petromyzon } \\
\text { marinus) }\end{array}$ & $\begin{array}{c}\text { GENSCAN000 } \\
00120210\end{array}$ & $\begin{array}{c}\text { GENSCAN000 } \\
00109335 / \\
\text { GENSCAN000 } \\
00056150\end{array}$ & ---- & $\begin{array}{c}\text { GENSCAN000 } \\
00079364 \\
\text { Contig } 32128\end{array}$ & --- & --- \\
\hline
\end{tabular}

Contig/Scaffold numbers are indicated when ENSEMBL accession number are not available

Dashes indicate genes not identified

the vertebrate SCT demonstrates the lowest conservation (less than 62\% within the PACAP-like subfamily) however this may be an artefact due to the restricted number of species in which it has been characterised. In addition, signature amino acid residues within or between peptide groups were also identified and they may reflect and support common evolutionary pathways and overlapping or specific functional roles. This includes, the PACAP $\mathrm{Y}^{13}$ and $\mathrm{A}^{24} \mathrm{~A}^{25}$ motif, the $\mathrm{V}^{5}, \mathrm{~N}^{9}, \mathrm{~F}^{13}$ and $\mathrm{N}^{24}$ for VIP, the motif $\mathrm{N}^{7} \mathrm{~K}^{8} \mathrm{~A}^{9}$ and residue $\mathrm{H}^{24}$ within $\mathrm{PRP}$, the $\mathrm{L}^{5}, \mathrm{~S}^{8}, \mathrm{E}^{24}$ and $\mathrm{I}^{27}$ for $\mathrm{PH}$, and the GHRH residues $\mathrm{N}^{8}, \mathrm{I}^{17}, \mathrm{Q}^{24}$ and $\mathrm{I}^{26}$ across the tetrapod and teleost members (Figure 2). Gene structure comparisons restricted to the mature peptide precursors revealed that PACAP and VIP exons are encoded in the same precursor as PRP and $\mathrm{PH}$, respec- tively [2,8] (Figure 3). Most common amino acids to the chordate PACAP and VIP members includes $\mathrm{R}^{14}$ and $\mathrm{K}^{15}$ and the motifs $\mathrm{M}^{17} \mathrm{~A}^{18} \mathrm{~V}^{19}$ and $\mathrm{V}^{26} \mathrm{~L}^{27}$ and they share a maximum of $37 \%$ amino acid sequence identity with PRP and $\mathrm{PH}$ indicating that after exon duplication considerable changes occurred. The latter peptides have a similar sequence $(81 \%$ similar) which is closely related to vertebrate GHRH ( $88 \%$ similar) with which they partition the residues $A^{2}, K^{12}, L^{14}, G^{15}$ and the motif $S^{18} A^{19} R^{20}$ and suggest a common evolutionary origin. The SCT gene has only been identified in tetrapods and the deduced peptide residues, $\mathrm{E}^{9}$ and $\mathrm{Q}^{20}$ are maintained in the mammalian and chicken homologues. The evolutionary origin of SCT is still enigmatic and it is proposed to have been lost in the fish lineage $[14,57]$. 


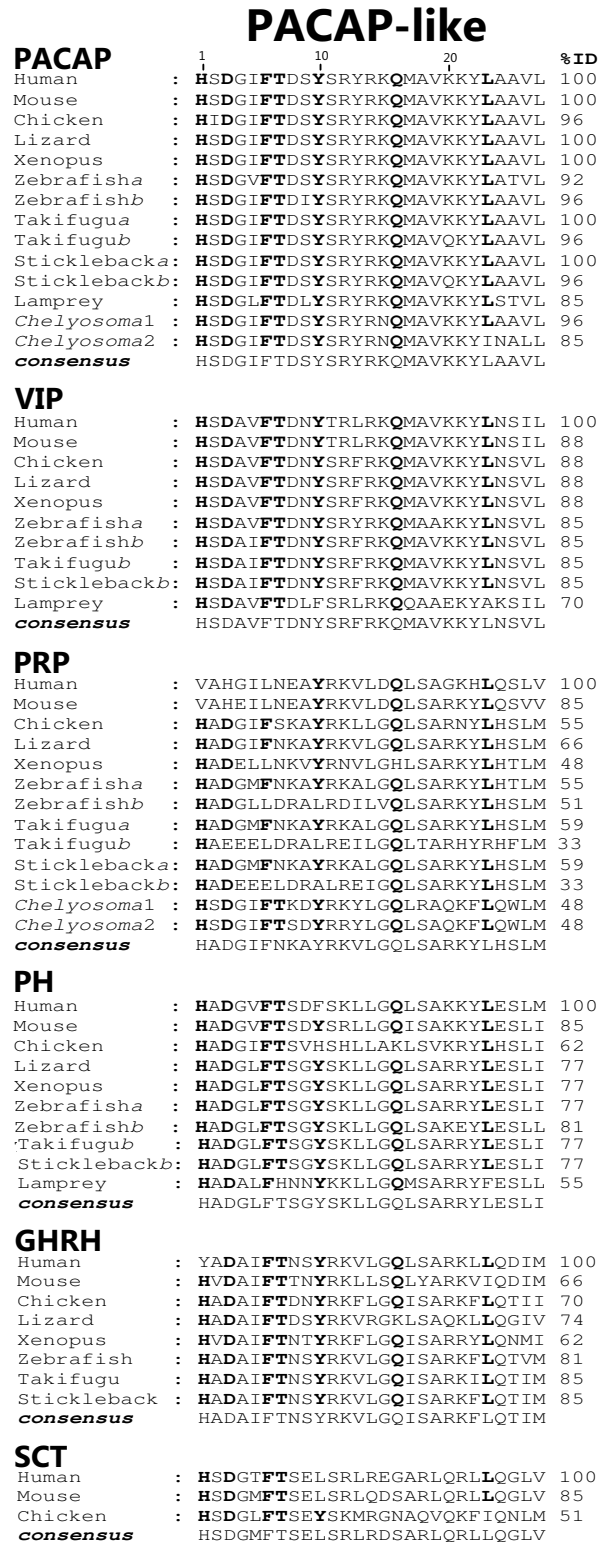

GCG

Mouse

Lizard

Lizard

Zebrafisha

Zebrafishb

Takifugua

Takifugub

Sticklebacka:

LampreyI

LampreyII

consensus

GLP1

Mouse

Lizard

Xenopusa

Xenopusb

Xenopusc

Zebrafisha

Zebrafishb

Takifugua

Takifugub

Sticklebacka:

LampreyI

consensus

GLP2

Human

Mouse

Chicken

Zebrafish

Takifugu

Stickleback

LampreyII

GIP

Mouse

Chicken

Lizard

Xenopus

Zebrafish

consensus

\section{GCG-like}

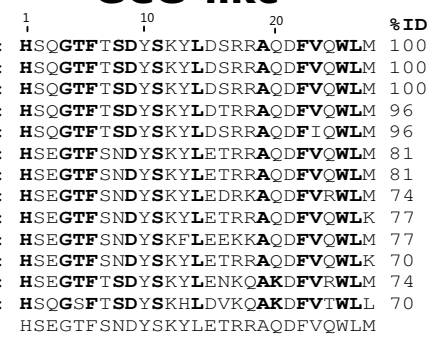

HSEGTF SNDYSKYLETRRAQDFVOWLM

HAEGTF T SDVSSYLEGQAAKEFIAWLV 100 HAEGTFT SDVS SYLEGQAAKEF IAWLV 100 HADGTYTSD IS SYLEGQAAKEF I AWLV 88 HAEGTFT SDVTOOLDEKAAKEFIDWLI 70 HAEGTYTNDVTEYLEEKAAKEF I EWL I 70 HAEGTFTNDMTNYLEEKAAKEFVGWLI 66 HADGTYT SDVS SYLODOAAKEFVSWLK 74 HAEGTYTSDVS SYLODOAAOSFVAWLK 74 HADGTF TSDVS SYLKDOA I KDFVARLK 70 HADGTYTSDVS TYLODOAAKEFVSWLK 70 HADGTF T SDVS SYLKEQAIKDFVDKLK 70 HADGTYT SDVS SYLQDQAVKEFVSWLK 66 HADGTF TNDMTSYLDAKAARDFVSWLA 55 HADGTFTSDVSSYLEDQAAKEFVAWLK

HADGSFSDEMNT ILDNLAARDF INWL I 100 HADGSFSDEMSTILDNLATRDF INWLI 92 HADGTF TSD INK ILDDMAAKEFLKWL I 55 HVDGSFT SDVNKVLDS I AAKEYLOWVM 40 HVDGTF I SDVNKVLD SMAAKEYLLWVM 37 HVDGSF T SDVNKVLDSLAAKEYLLWVM 44 HSDGSFTNDMNVMLDRMSAKNFLEWLK 48 HADGSFTSDMNKI LDSMAAKEF LNWLI

D




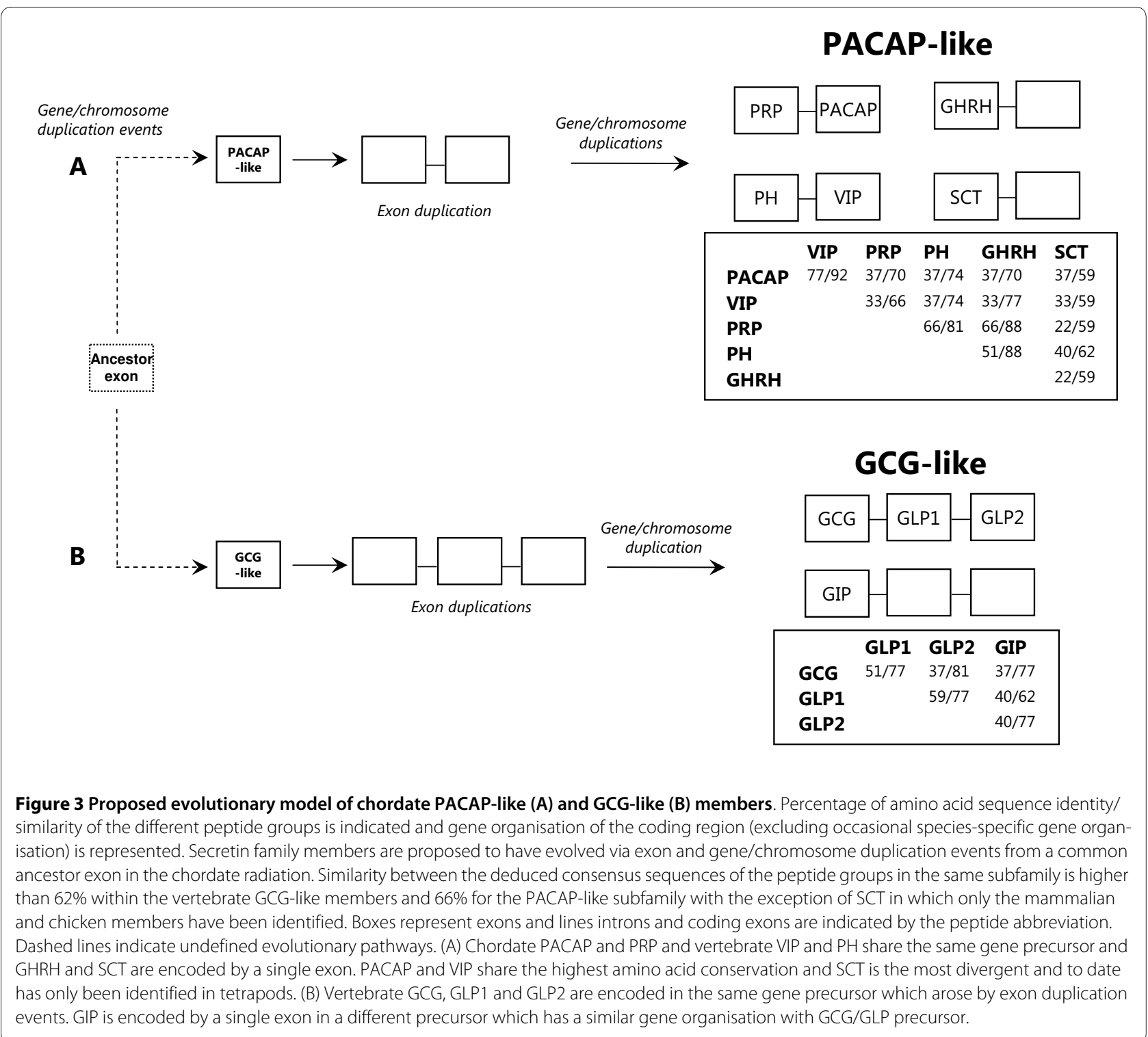

Members of the GCG-like subfamily share at least $62 \%$ amino acid similarity and GLP1 and GLP2 have the highest identity (59\%, Figure 3 ). In addition to the general sequence conservation of the GCG-like subfamily members, conserved amino acid positions within the vertebrate peptide groups were also identified (Figure 2). This includes $\mathrm{S}^{2}, \mathrm{Q}^{24}, \mathrm{M}^{27}$ and the motifs $\mathrm{R}^{17} \mathrm{R}^{18}$ and $\mathrm{Q}^{20} \mathrm{D}^{21}$ for GCG; $\mathrm{V}^{10}, \mathrm{~S}^{12}$ and $\mathrm{Q}^{17}$ for GLP1; $\mathrm{S}^{5}, \mathrm{~N}^{11}$ and $\mathrm{L}^{23}$ for GLP2; and $\mathrm{Y}^{1}$ and $\mathrm{L}^{27}$ in GIP. The GLP1 and GLP2 peptides are encoded in the same precursor (proglucagon precursor) as GCG with which they share $77 \%$ and $81 \%$ amino acid sequence similarity, respectively and the mature peptide coding exons are proposed to be a consequence of exon duplication events. Vertebrate GIP shares 37\% and 40\% sequence identity with GCG and GLPs, respectively and studies based upon gene structure comparisons suggest the latter emerged from the same exon as GCG, however the results of sequence analysis are inconclusive and more data is required $[2,27]$.

\section{The secretin members in non-vertebrates}

Database searches using the vertebrate nucleotide and peptide sequences of secretin family members and the duplicate urochordate Chelyosoma productum PRP/ PACAP transcripts failed to identify conserved sequence and structure homologues in genome or EST databases from porifera, cnidaria, protostome and early deuterostomes (Ciona, amphioxus and sea urchin). Instead, short sequence matches were identified in unrelated genes or non-annotated genome segments. In depth analysis of the best matches, revealed homologies for the central region and $\mathrm{C}$-terminal ends (outside the bioactive core) of the chordate mature peptides and, when the invertebrate fragments were used to interrogate vertebrate data- 
bases, they failed to retrieve a secretin family homologue suggesting that members of this family are absent from non-vertebrate genomes.

The exception is PACAP for which a highly conserved partial sequence corresponding to the exon encoding the mature peptide ( $>89 \%$ amino acid identity, [8]) has been isolated in Hydra magnipapillata (AB083650), in the tunicate, Halocynthia roretzi (AB121759) and in several protostomes such as planarian (Dugesia japonica, AB083649), crab (Eriocheir japonica, AB121765), squid (Sepioteuthis lessoniana, AB083651) and cockroach (Periplaneta americana, AB083652) [9]. Database searches using the non-vertebrate PACAP nucleotide or deduced peptide sequences failed to retrieve homologues from protostomes with available genome data (Helobdella robusta, Capitella sp. I, Lottia gigantea, Daphnia pulex, Drosophila melanogaster, Aedes aegypti, Anopheles gambiae, Caenorhabditis elegans and Caenorhabditis briggsae). Moreover, searches performed in Hydra magnipapillata and related species Nematostella vectensis genome assemblies with the Hydra PACAP nucleotide or deduced peptide sequence also failed to confirm the existence of a gene encoding PACAP. In early deuterostomes, searches using the Chelyosoma productum PRP/PACAP nucleotide or deduced peptide sequences in Ciona intestinalis and Ciona savignyi genomes or available tunicate ESTs failed to identify possible sequence homologues in urochordate. Taken together these results raise questions about the authenticity of the previously reported sequences.

An alternative strategy utilized a secretin family prototype sequence model based on the assumption that the chordate members arose from a common precursor gene which duplicated to give PACAP-like and GCG-like subfamily exons (Figure 2 and 3 ). The prototype sequence deduced in silico was $\mathrm{H}^{1} \mathrm{~A}^{2} \mathrm{D}^{3} \mathrm{G}^{4} \mathrm{~T}^{5} \mathrm{~F}^{6} \mathrm{~T}^{7} \mathrm{~S}^{8} \mathrm{D}^{9}$ $\mathrm{Y}^{10} \mathrm{~S}^{11} \mathrm{xxL}^{14} \mathrm{xQ}^{16} \mathrm{xxA}^{19} \mathrm{~K}^{20} \mathrm{xF}^{22} \mathrm{xxW} \mathrm{W}^{25} \mathrm{~L}^{26}$ ( $\mathrm{x}$ represents variable position) and contains 18 conserved amino acid positions and high conservation was found for the $\mathrm{N}$-terminal region. Structural characterisation using Pfam analysis classified the generated prototype sequence as a Hormone_2 member (PF00123, which includes the vertebrate secretin family members) [58] and sequence similarity searches performed retrieved secretin family members in vertebrates but failed to identify potential members in non-vertebrates. A second approach using HMM models and searching the general NCBI nonredundant (nr) peptide and an invertebrate subset of the NCBI nucleotide and EST (est_others) databases corroborated the preceding results.

\section{Phylogenetic analysis}

The optimal maximum likelihood (ML) tree with bootstrap support values higher than 50\% is presented in Fig- ure 4. Despite the high level of sequence identity and short sequences utilized, phylogenetic analyses of the chordate mature peptides (1-27 aa) and their corresponding nucleotide sequences resulted in similar tree topologies and suggests that members of the secretin family share a common ancestry. In the optimal ML tree presented in Figure 4 two clades PACAP-like and GCG-like were obtained suggesting that after ancestral exon duplication two main peptide subgroups emerged and underwent distinct evolutionary trajectories. Similar tree topologies were obtained using Bayesian approaches (Supplementary table 2) and a PACAP-like derived clade includes the peptides PACAP, PRP, PH, VIP, GHRH and SCT and a GCG-like clade the peptides GCG, GLP1, GLP2 and GIP. The Chelyosoma PACAP deduced peptide sequences always grouped with the vertebrate peptide sequence homologues and the tunicate PRPs did not cluster with any particular peptide clade and in all the analysis performed tended to be more closely related to the tetrapod SCT.

\section{Gene environment comparisons}

The immediate gene environment of vertebrate secretin members was compared and indicates that PRP/PACAP, GCG/GLP, and GHRH genome regions are syntenic and gene order is in general maintained (Figure 5). The GCG/ GLP gene environment shares at least 3 genes (KCNH7, IFIH1 and SLC4A10), PRP/PACAP, 2 genes (YES1 and METTL4) and GHRH, 1 gene (RPN2) when equivalent genome regions are compared between Takifugu, Xenopus, chicken and human. The VIP and GIP genomic regions are poorly conserved and no gene synteny or gene order was identified (data not shown). Moreover, searches also failed to identify conservation of gene linkage between the different vertebrate secretin family members.

In Takifugu, the neighbouring genes of the paralogue GCG/GLP (SLC4A10 and KCNH7, N000046 and N000036) and PACAP (YES1, N000223 and N000080) genes were also duplicates supporting the teleost gene or genome duplication event. Searches were extended to the lamprey and lizard genomes but contiguous sequences were too small to confirm the existence of gene environment conservation. Comparison of the SCT genome region between chicken (chromosome 5) and human (chromosome 11) revealed they are highly conserved and the order of 5 genes (MUCDHL, DRD4, DEAF1, EPS8L2 and PDDC1) is maintained. In Xenopus genome, the chicken and human SCT flanking genes are localised in the amphibian scaffold_296 and in Takifugu, where a gene homologue is proposed to be absent, they are distributed in two distinct genome regions: MUCDHL and DRD4 are localised in scaffold N000002 and the remaining genes in scaffold N000328 suggesting the existence of 


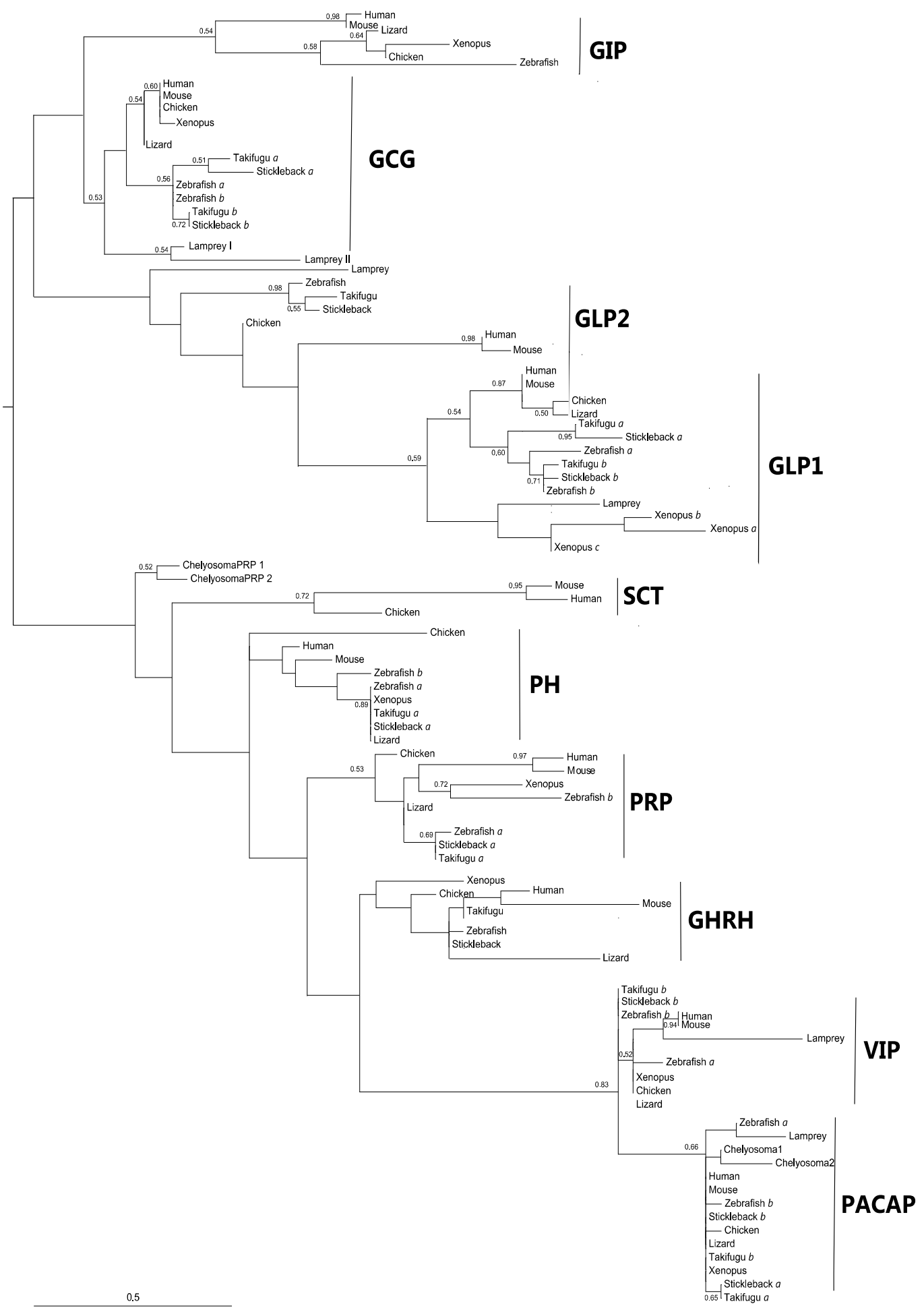

Figure 4 Evolutionary analysis of the chordate secretin family members. The maximum likelihood (ML) optimal tree topology is presented and was constructed with Phyml 3.0 [99]. ML bootstrap values higher than $50 \%$ are indicated at nodes and to facilitate interpretation a hypothetical root was added to the tree between the PACAP-like and GCG-like clades based upon gene structure evidence and proposed models for secretin family evolution. The different peptide groups are indicated and teleost duplicate genes are marked by $a$ and $b$; Xenopus GLP1 exons by $a, b$ and $c$. Accession numbers of the sequences used are described in Table 2 and for human and mouse members are: PHM/NIP (P01282 and P32648); PRP/PACAP (P18509 and O70176); GHRH (P01286 and P16043); GCG/GLPs (P01275 and P55095); GIP (P09681 and P48756); and SCT (P09683 and Q08535), respectively. 
Takifugu
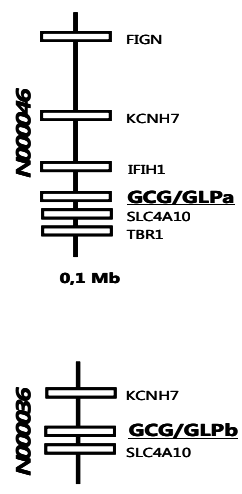

0,04 Mb

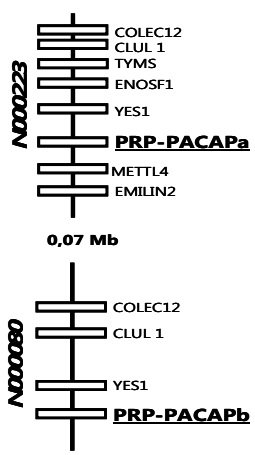

$0,04 \mathrm{Mb}$

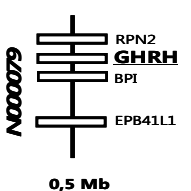

Xenopus

Scaffold 51

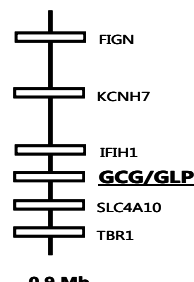

Scaffold 420

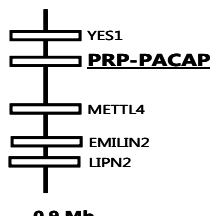

Scaffold 38

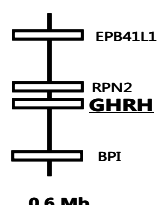

Chicken

Chr 7

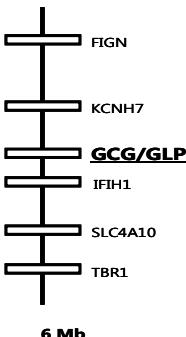

Chr 2

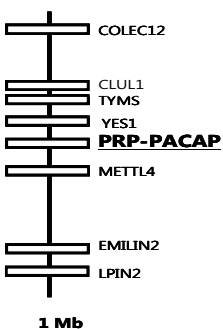

Chr 20

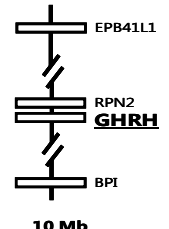

$10 \mathrm{Mb}$

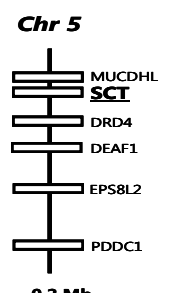

\section{Human}

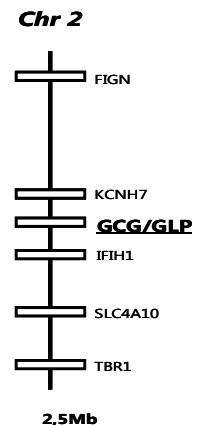

Chr 18

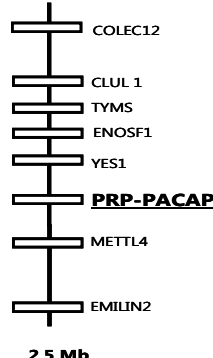

Chr 20

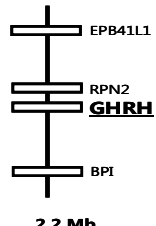

Chr 11

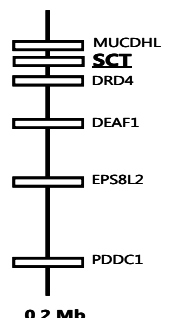

Figure 5 Gene environment comparisons of the GCG/GLPs, PRP/PACAP, GHRH and SCT genes in Takifugu, Xenopus, chicken and human Homologue genes were identified using sequence similarity approaches with the Takifugu genes. Takifugu scaffolds are named according to the Assembly 4 available at [93] and have a direct correspondence with ENSEMBL (eg: N000046 corresponds to Takifugu Ensembl scaffolds_46). Genes were named based on HUGO annotation and the size of the genome regions analysed indicated within brackets. Genes are represented by boxes and genomic regions are indicated by lines. The figure is not drawn to scale and genes are positioned according to their relative distance in the genome assembly. For simplicity, only homologue genes are represented and GCG/GLP, PRP/PACAP, GHRH and SCT genes are edited in bold and underlined. 
a conserved gene block prior to the emergence of the tetrapod gene (data not shown).

In order to identify a potential secretin family genome region in non-vertebrates, the conserved vertebrate gene environment was used to retrieve homologues in the $C$. elegans, Drosophila and Ciona genomes. Genes sharing similarity in sequence to those flanking the vertebrate GCG/GLP, PRP/PACAP and GHRH loci were identified although the genes encoding secretin family members were absent (Figure 6). In C. elegans the genes $d r h-3$, abts-1, src-1 and M01A10.3 map to chromosome I and are respectively homologues of the human IFIH1 and SLC4A10 on chromosome 2, YES1 on chromosome 18 and RPN2 on chromosome 20. In Drosophila, sei and CG6370 are localised in chromosome $2 \mathrm{R}$ and are the homologues of human $K C N H 7$ and RPN2 and the fruitfly Dcr-2 and CG14906 genes in chromosome 3R the correspondent in sequence of the human IFIH1 and METTL4, respectively.

In the tunicate genome, homologues of the vertebrate secretin family flanking genes were identified scattered in the Ciona genome assembly. Homologues of human KCNH7 (ENSCING00000000802, scaffold_167), IFIH1 (ENSCING00000009744, scaffold_44) and SLC4A10 (ENSCING00000006669, chromosome 9p) genes which flank GCG/GLP in vertebrates were identified. The conserved gene environment of the vertebrate PRP/PACAP genes: YES1 (ENSCING000000008550 on scaffold_65) and METTL4 (ENSCING00000013236 on chromosome 8q) genes are also present as well the putative urochordate homologue of the RPN2 gene (ENSCING00000009122) conserved in the vertebrate GHRH genome region.

In the $C$. elegans genome chromosome 1 contained homologues of the genes which flank PRP/PACAP, GCG/ GLP and GHRH in vertebrates. This suggests that this chromosome may be the protostome genome fragment that most resembles the potential metazoan ancestral secretin genome region from which the vertebrate members emerged. However, detailed analysis of chromosome positions (src-1, 1566932 to $1580204 \mathrm{bp} ;$ M01A10.3, 5550508 to $5549145 \mathrm{bp}$; $d r h-3,7820837$ to $7826373 \mathrm{bp}$; and abst-1, 8307558 to $8296909 \mathrm{bp}$ ) revealed they are not mapped in close proximity and do not forms a gene cluster. Moreover, no conserved linkage between the putative Drosophila and the C. elegans gene homologues exists.

\section{Discussion}

Comparative analysis of data from phylogenetically distant organisms is a major contributor for understanding gene and gene family evolution and the role of function and regulation in this process. The identification of gene homologues in vertebrates and early metazoan genomes provides a unique opportunity to perform comparative studies and to investigate gene family ancestries. The secretin family is a well-studied group of peptides which activate specific receptors of family 2 GPCRs to bring about their pleotropic actions in vertebrates. Secretinlike family GPCRs have been identified and cloned from non-vertebrate genomes $[6,14,59,60]$ and their putative peptide ligands identified by immunohistochemistry (IHC) using antisera raised against the mammalian peptide homologues (Table 1). Both peptides and their corresponding receptors are proposed to have arisen by gene duplication events prior to the vertebrate radiation $[2,6,8,10,11,18]$ and they represent an interesting model for studies of receptor-ligand evolution.

In the present study, despite extensive in silico database searches it was not possible to identify members of the secretin peptide family in non-vertebrates regardless of the report of a full-length PACAP cDNA in the tunicate, Chelyosoma productum [7] and cDNA of the PACAP coding exon in crab, cockroach, squid, planarian and Hydra magnipapillata [7,9]. Moreover, using the partial PACAP cDNA previously identified in Hydra magnipapillata (a cnidaria) to interrogate its sequenced genome [61] failed to identify the gene homologue.

It seems unlikely that the failure to identify PACAP in non-vertebrates was related to the methodology used as a similar approach has been successfully utilized to identify the gene encoding the active nonapeptide hormone, vasotocin/vasopressin in the amphioxus genome assembly and also the gene loci in several chordates including teleosts [62]. In fact, the existence of neurohypophysial hormones (eg. vasopressin and oxytocin) in deuterostomes and protostomes has been amply confirmed by the isolation of both genes and peptides from representatives of a number of different phyla (reviewed in [62]). Similarly, conserved sequence homologues of vertebrate neuropeptide $\mathrm{Y}$ family members have been isolated from molluscs and also from fruit-fly and mosquito and GPCR ligand-receptor pairs similar to the vertebrate NPY system have been characterised [63-65].

A comprehensive in silico analysis of the fully sequenced Drosophila genome identified and classified GPCRs and compared their number to putative neuropeptide ligands. Although 5 secretin family GPCR members were identified in the arthropod genome, only two potential ligands, corticotrophin releasing factor (CRF)related peptides and amnesiac genes, unrelated to chordate secretin peptide family members were predicted [66]. In contrast, recent studies performed in molluscs (Helix pomatia) using IHC and MALDI-TOF/TOF identified partial peptides with a similar mass to vertebrate PACAP in the snail whole hemolymph and CNS extracts [67]. Should the identity of the peptide be confirmed by sequencing taking in consideration the results of the present study a new paradigm will be required to explain secretin family evolution. 


\section{Human}
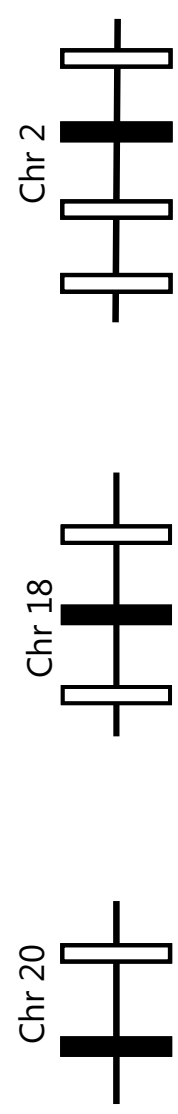

Ciona

ENSCING00000000802

(Scaffold_167)

GCG/GLP

IFIH1

SLC4A10

YES1

PRP/PACAP

METTL4

RPN2

ENSCING00000009122

(2q)

GHRH

(9p)

ENSCING00000008550

(8q)
Drosophila

C.elegans unc-103

(III)

drh-3

Dcr-2

(3R)

Ndae1

(2L)

abts-1

(I)

$\operatorname{Src64B}$

(3L)

src-1

(I)

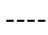

CG14906

(3R)

C18A3.1

(II)

CG6370

(2R)

M01A10.3

(I)

Figure 6 Comparisons of conserved flanking genes of human PRP/PACAP, GHRH and GCG/GLP with the putative homologue regions in Ciona, Drosophila and C. elegans. Non-vertebrate genomes were accessed using the ENSEMBL annotation. Accession numbers of the human neighbouring genes: $\mathrm{KCNH7}$ (EAX11346); interferon induced with helicase C domain 1 (IFIH1, EAX11352); Solute carrier family 4, sodium bicarbonate transporter, member 10 (SLC4A10, AAI36270), viral oncogene yes-1 homolog 1 (YES1, NP_005424), Methyltransferase like 4 (METTL4, AAl36768), ribophorin II, (RPN2, NP_002942).

There is evidence that genes for amnesiac in Drosophila and maxadilan in sand-fly might encode functional homologues of the vertebrate PACAP despite their lack of sequence similarity $[2,68-70]$ and the maxadilan peptide is able to activate mammalian $\mathrm{PAC}_{1}$ receptors in vitro $[71,72]$. The activation of family 2 GPCRs members by the secretin family of ligands has been linked to their well conserved structure $[53,54]$ which comprises an alpha helix in the mid and $\mathrm{C}$-terminal region and an $\mathrm{N}$-terminal loop. The region of maxadilan implicated in $\mathrm{PAC}_{1}$ receptor activation has an identical structure to the $\mathrm{N}$-terminal region of secretin family ligands and contains key amino acids involved in receptor activation (reviewed by [69]). In fact, mutation analysis with maxadilan demonstrated that despite its greater size compared to vertebrate secretin family peptides, the disruption of four conserved cysteine residues ( 1 - 5 and 14 - 51) responsible for the formation of two disulfide bonds led to loss of activity [69]. Taking into consideration the degree of conservation of the N-terminal ligand binding domain of the secretin family GPCRs [14] and their relative promiscuity [73] it is unsurprising that protostome peptides activate vertebrate receptors. In nematode and Drosophila, PDF (Pigment Dispersing Factor) stimulated the homologues of vertebrate secretin GPCRs but they were not stimulated by secretin family members $[14,59,60]$. These observations suggest that specificity of the receptor members has changed during evolution and may explain the failure to identify conserved ligands. 
A general model to explain peptide ligand binding and receptor activation has emerged recently for class B GPCRs (secretin family) [74]. The proposed mechanism, known as the "two-domain model" suggests that initial ligand-receptor interactions are mediated by the central and C-terminal peptide segments with the extracellular $\mathrm{N}$-terminal receptor region and that activation occurs subsequently when the bioactive $\mathrm{N}$-terminus of the ligand binds the receptor juxtamembrane domain [75]. In this context, the identification in the present study of putative "signature" amino acids conserved across taxa for each peptide groups may explain differences in selection and affinity for receptors. For example, mutation of conserved residues within the C-terminal region of VIP revealed that substitution of $\mathrm{L}^{23}$ (common to PACAP-like subfamily members) decreased peptide biological activity without altering the predicted structure [76]. $\mathrm{D}^{3}$ is conserved across the PACAP-like peptides and this residue has a role in adenyl cyclase (AC) stimulation and interacts with basic residues $\left(\mathrm{R}^{188}\right.$ and $\left.\mathrm{K}^{195}\right)$ in the second transmembrane helix of VPAC [77]. Similarly, $\mathrm{D}^{9}$ which is conserved across the GCG-like members is essential in the activation of mammalian GCGR [78]. It will be of interest in the future to study the role of unique amino acid residues/motifs identified in the present study within the $\mathrm{N}$ terminal and C-terminal regions of each peptide group.

Recently, a Darwinian evolutionary model was proposed to explain the origin of steroid hormones and their receptors and may also explain the emergence of metazoan secretin peptide-receptor pairs. The steroid hormones and receptors were proposed to have evolved through a molecular exploitation process in which structurally adapted receptors evolved prior to ligand emergence $[79,80]$. By reconstructing the sequence of the ancestral steroid receptors (eg. corticoid receptor) the authors verified that they are activated by hormones (eg. aldosterone) that only emerged in the tetrapod lineage. At present, evolutionary comparisons of the metazoan receptor members and secretin peptide family suggests that, receptors emerged prior to the ligands which were subsequently acquired as a consequence of genome evolution in the chordate radiation. Generally, two major gene or genome duplication events are proposed to have occurred at the origin of vertebrates and have accompanied increased organismal complexity and emergence of gene novelties $[81,82]$. Whilst the majority of gene duplicates were probably lost as a consequence of their functional redundancy, some were fixed in the genome by the gain of new biological functions or partitioning the function of the ancestral counterpart and this may be the case for the secretin family GPCRs and their ligands $[8,17,83]$.

The origin of the chordate secretin peptide family has been previously associated with the insect adipokinetic hormone (AKH) and AKH-Precursor Related Peptides
(APRP) precursor evolution [84]. Despite their low sequence similarity, the arthropod AKH and APRP precursor was found to share a similar gene organisation and comparable functions with vertebrate GCG and GHRH and they were proposed to have shared common origin prior to protostome-deuterostome divergence (approximately 600 million years ago). However, against this hypothesis is the recent demonstration that insect ADK signals through a gonadotropin-releasing hormone (GnRH) like receptor (members of family 1 GPCRs) and also the isolation of putative nematode AKH-GnRH related precursors suggesting that the invertebrate ADK members may share common evolution with the metazoan GnRH system [85,86].

\section{Conclusions}

The present study does not confirm the results of IHC studies in the early 70's and 80's which identified putative invertebrate secretin family members using antisera against mammalian peptides. It was not possible to identify sequence homologues of the Chelyosoma productum PRP/PACAP peptides in the sequenced Ciona genomes, although at least 8 putative secretin-like family GPCRs have been reported [14]. The previous facts taken with i) the identification in snail of a putative PACAP peptide; and ii) the activation of a secretin-like family GPCRs in nematode and Drosophila by PDF but not by vertebrate secretin family members makes it difficult to establish when the peptide members emerged in the deuterostome lineage. It is hypothesised that the emergence of the full suite of receptors and their ligands accompanied the rapid genome changes during chordate evolution. The ancestral secretin family gene probably arose as part of an existing gene or gene fragment and via exon and gene duplication events generated the existing suite of family members (Figure 3). This occurred after the emergence of the secretin family GPCRs and led to the establishment of novel and specific receptor ligand interactions that contributed to the generation of novel physiological functions. In contrast, to other peptide families, such as NPY/ PYY and Oxytocin/vasopressin which stimulate receptors of family 1 GPCRs and are highly conserved from protostomes to deuterostomes, members of the secretin family GPCRs appear to have adopted new ligands during evolution.

\section{Methods}

\section{Data mining}

Using comparative sequence approaches the existence of putative non-vertebrate secretin family members were investigated in publicly available protostome and early deuterostome genome, EST and protein databases. The complete nucleotide and amino acid sequences of human secretin family members (PHM/VIP, P01282; PRP/ 
PACAP, P18509; SCT, P09683; GHRH, P01286; GIP, P09681; and GCG/GLP, P01275) mature peptides and their homologues in zebrafish and tunicate Chelyosoma productum PRP/PACAP precursors were used to interrogate databases (Figure 1, Additional file 1). Searches were performed in the metazoan genomes of porifera (Amphimedon queenslandica), cnidarians (Nematostella vectensis and Hydra magnipapilata), planarian (Schmidtea mediterranea), annelids (Helobdella robusta and Capitella capitata), mollusc (Lottia gigantea), crustacean (Daphnia pulex), insects (Drosophila melanogaster, Aedes aegypti and Anopheles gambiae); nematodes (Caenorhabditis elegans and Caenorhabditis briggsae); and in the early deuterostomes, sea urchin (Strongylocentrotus purpuratus Build 2), cephalochordate (Branchiostoma floridae) and urochordates (Ciona savignyi and Ciona intestinalis); and also in the vertebrate sea lamprey (Petromyzon marinus), teleosts (zebrafish, Danio rerio; Takifugu rubripes; Tetraodon nigroviridis; medaka, Oryzias latipes; stickleback, Gasterosteus aculeatus) and tetrapods, frog (Xenopus tropicalis), lizard (Anolis carolinensis) and chicken (Gallus gallus). Searches of the Takifugu genome were also performed in http:// fugu.nimr.mrc.ac.uk/blast. To substantiate the results, further searches for secretin family members were also carried out in the NCBI EST data sets for porifera (Porifera (taxid:6040), cnidaria (Cnidaria (taxid:6073), protostomes (Protostomia (taxid:33317)) and early deuterostome (Echinoderms (taxid:7586); Cephalochordata (taxid:7735); Urochordata (taxid:7712) and also in species specific EST databases for the planarian (Schmidtea mediterranea), crab (Celuca pugilator), pacific oyster (Crassostrea gigas) and mussel (Mytilus edulis) (Additional file 1). In addition, the complete nucleotide precursor or the sequence corresponding to the deduced mature peptide of secretin family members in deuterostome were used to interrogate the general nucleotide $(\mathrm{nr} / \mathrm{nt})$ and protein databases (nr) available at NCBI [9] and UniProt [87] using the BLAST programme.

For small mature peptide sequences the BLAST algorithm was adjusted (scoring matrix PAM30, word size 2, highest expected value parameters, low complexity filter off, no adjustment) to permit identification of short peptide hits with strong similarities. Searches using short nucleotide sequences were also performed with word size 7; expected value 1000 and low complexity filter off. Best matches with significant scores or low E values $<0.01$ were retrieved and analysed.

Searches using a hidden Markov model were performed with the HMMER3 (3.03b) [88] suite of software on the NCBI non-redundant (nr) peptide, and custommade invertebrate nucleotide (nt) (1614126 records) and est_others (ests minus human and mouse) (11209486 records) databases using hmmsearch. Subset databases were constructed to reduce the computational burden of performing a HMMER3 search against the complete NCBI nucleotide and EST databases. The invertebrate subset databases were constructed by querying the NCBI databases using Entrez for all invertebrate GI numbers (Metazoa NOT Vertebrata) for both nt and est_others and filtered using fastacmd (part of the NCBI BLAST package). Peptide searches were performed with the Pfam model for the secretin peptide family members (Hormone_2 member, PF00123) and nucleotide queries with a model constructed in HMMER3 (3.03b) using the nucleotide aligned sequences of the 1-27 aa mature peptide regions of the secretin family members represented in Figure 2.

\section{Sequence comparisons}

The potential secretin family members identified were compared with existing vertebrate members. The nonvertebrate sequences that shared similarity with previously annotated genes or gene intron regions were discarded and the remaining candidates used to interrogate the NCBI database to confirm identity and failed to retrieve a homologue of the vertebrate secretin family. In contrast, homologues in vertebrate datasets were identified and the deduced amino acid sequences of the retrieved transcripts or predicted exon coding regions were compared using ClustalX 2.0 [89] with the conserved mature peptide region 1-27 aa of representatives of the secretin family with the exception of human GLP1 in which 5-32 aa were used that correspond to a unique coding exon. Peptide similarities/identities were determined using the GeneDoc programme [90] and amino acid consensus sequences within each peptide group were deduced and compared to demonstrate general levels of conservation for each subfamily. A prototype peptide representative of the chordate secretin family was constructed by fusing the most abundant amino acid residues within the PACAP-like and GCG-like peptides members. The in silico deduced sequence was submitted to Pfam [58] analysis to confirm identity as a secretin member and used to search the vertebrate and non-vertebrate NCBI databases with BLAST and adjusted parameters to identify homologues.

\section{Phylogenetic analysis}

Phylogenetic analyses were performed using the ClustalX 2.0 alignment of the 1-27 aa mature peptide region of secretin members. The amino acid sequence alignment produced was analysed with PROTTEST to select the model of protein evolution that best fits dataset [83] and phylogenetic analyses were conducted using 95 taxa with the maximum likelihood and Bayesian estimation methods (MrBayes and PhyloBayes, Additional file 2). The maximum likelihood analysis was carried out using 
Phyml 3.0 [85] with 100 bootstrap replicates with a JTT substitution model with a discrete gamma distribution of rates among sites with 4 categories $(\Gamma)$. A search for the optimal ML tree was also performed. Bayesian estimation using MrBayes [91] was performed with the Dayhoff model with $\Gamma$ and PhyloBayes [92] with the CAT model plus $\Gamma$. The MrBayes analysis was conducted with two MCMC runs (each with 4 chains) for 200,000 generations with 20,000 samples. The PhyloBayes CAT analysis was performed using 2 independent run replicates (40727 and 40382 generations, respectively). Likelihoods were plotted against generation time and the MCMC chains were assumed to have reached stationarity when the curve plateaued. Phylogenetic sequence analysis was also performed using the nucleotide sequences of the 1-27 mature peptide domains with the ML method as previously described and the GTR model plus $\Gamma$ and the individual peptide clades present in both nucleotide and amino acid trees obtained were similar (data not shown).

\section{Gene environment comparisons}

The gene environment of vertebrate secretin family members was determined to identify potentially conserved gene blocks; these were then used to search for putative ancestral secretin genome-like regions in C. elegans, Drosophila and Ciona assemblies. The Takifugu NIX annotated scaffolds [93] were used as a guide to characterise the Xenopus (Xenopus tropicalis) [94], the chicken and human homologue regions [95]. The NIX annotated scaffolds from Takifugu were used as they had greater information content than the homologue data deposited in ENSEMBL. The conserved vertebrate gene environment identified the genes YES1 and METTL4 for PRP/PACAP; the gene RPN2 for GHRH; and the KCNH7, IFIH1 and SLC4A10 genes within the vertebrate GCG/ GLP genomic region. The, C. elegans, Drosophila and Ciona genomes were assessed using the ENSEMBL assembly annotation and homologues identified and compared with the vertebrate homologue region.

\section{Additional material}

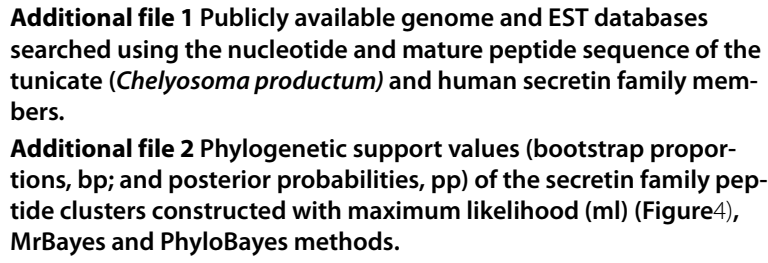

\section{Abbreviations}

VIP: (Vasoactive Intestinal Peptide); PACAP: (Pituitary Adenylate Cyclase-Activating Polypeptide); SCT: (Secretin); GHRH: (Growth Hormone Releasing Hormone); PRP: (PACAP-Related Peptide); PH: (Peptide Histidine); PHI: (PHIsoleucine); PHM: (PH-Methionine): GCG: (Glucagon); GLP: (GCG-like); GIP: (Glucose-dependent Insulinotropic Peptide); GPCRs: (G-Protein Coupled Receptors).

\section{Authors' contributions}

The majority of the practical work was carried out by JCRC in collaboration with FAV and ASG. JCRC and DMP planned the study, wrote, analysed the data and critically revised the manuscript for important intellectual content. All authors read and approved the final manuscript.

\section{Acknowledgements}

The authors acknowledge the input of the reviewers which improved the manuscript and thank Cymon Cox for help with the phylogenetic analysis and HMM searches. This work was co-financed by POCI 2010 and the European social funds attributed by the Portuguese National Science Foundation (FCT) to project (POCI/CVT/61052/2004) and CCMAR Pluriannual project and PhD fellowship (BD/17630/04) to FV.

\section{Author Details}

Centre of Marine Sciences (CCMAR), Universidade do Algarve, Campus de Gambelas, 8005-139 Faro, Portugal

Received: 16 November 2009 Accepted: 6 May 2010

Published: 6 May 2010

\section{References}

1. Jorpes JE, Mutt V: The gastrointestinal hormones, secretin and cholecystokinin-pancreozymin. Ann Intern Med 1961, 55:395-405.

2. Sherwood NM, KrueckI SL, McRory JE: The Origin and Function of the Pituitary Adenylate Cyclase-Activating Polypeptide (PACAP)/Glucagon Superfamily. Endocr Rev 2000, 21:619-670.

3. Irwin DM: Molecular evolution of mammalian incretin hormone genes. Regulatory peptides 2009, 155:121-130.

4. Vaudry D, Gonzalez BJ, Basille M, Yon L, Fournier A, Vaudry H: Pituitary adenylate cyclase-activating polypeptide and its receptors: from structure to functions. Pharmacol Rev 2000, 52:269-324.

5. Nordstrom KJ, Lagerstrom MC, Waller LM, Fredriksson R, Schioth HB: The Secretin GPCRs descended from the family of Adhesion GPCRs. Mol Biol Evol 2009, 26:71-84.

6. Harmar AJ: Family-B G-protein-coupled receptors. Genome Biology 2001, 2:REVIEWS3013.

7. McRory J, Sherwood NM: Two Protochordate Genes Encode Pituitary Adenylate Cyclase-Activating Polypeptide and Related Family Members. Endocrinology 1997, 138:2380-2390.

8. Cardoso JC, Vieira FA, Gomes AS, Power DM: PACAP, VIP and their receptors in the metazoa: insights about the origin and evolution of the ligand-receptor pair. Peptides 2007, 28:1902-1919.

9. National Center for Biotechnology Information: [http:// www.ncbi.n/m.nih.gov/]

10. Campbell RM, Scanes CG: Evolution of the growth hormone-releasing factor (GRF) family of peptides. Growth Regul 1992, 2:175-191.

11. Montero M, Yon L, Kikuyama S, Dufour S, Vaudry H: Molecular evolution of the growth hormone-releasing hormone/pituitary adenylate cyclase-activating polypeptide gene family. Functional implication in the regulation of growth hormone secretion. J Mol Endocrinol 2000 25:157-168

12. Hoyle $\mathrm{CH}$ : Neuropeptide families: evolutionary perspectives. Regul Peptides 1998, 73:1-33

13. Hill CA, Fox AN, Pitts RJ, Kent LB, Tan PL, Chrystal MA, Cravchik A, Collins $\mathrm{FH}$, Robertson HM, Zwiebel L: G protein-coupled receptors in Anopheles gambiae. Science 2002, 298:176-178.

14. Cardoso JC, Pinto VC, Vieira FA, Clark MS, Power DM: Evolution of secretin family GPCR members in the metazoa. BMC Evol Biol 2006, 6:108.

15. Nordstrom KJ, Fredriksson R, Schioth HB: The amphioxus (Branchiostoma floridae) genome contains a highly diversified set of $\mathrm{G}$ protein-coupled receptors. BMC Evol Biol 2008, 8:9

16. Kamesh N, Aradhyam GK, Manoj N: The repertoire of G protein-coupled receptors in the sea squirt Ciona intestinalis. BMC Evol Biol 2008, 8:129.

17. Cardoso JC, de Vet EC, Louro B, Elgar G, Clark MS, Power DM: Persistence of duplicated PAC1 receptors in the teleost, Sparus auratus. BMCEvol Biol 2007, 7:221.

18. Tam JK, Lee LT, Chow BK: PACAP-related peptide (PRP)-molecular evolution and potential functions. Peptides 2007, 28:1920-1929.

19. Irwin DM: Molecular evolution of proglucagon. Regul Peptides 2001, 98:1-12. 
20. Yoo SJ, You S, Kim H, Kim SC, Choi YJ, El Halawani M, Farris J, Foster DN: Molecular cloning and characterization of alternatively spliced transcripts of the turkey pituitary adenylate cyclase-activating polypeptide. Gen Comp Endocrinol 2000, 120:326-335.

21. Mirabella N, Squillacioti C, Colitti M, Germano G, Pelagalli A, Paino G: Pituitary adenylate cyclase activating peptide (PACAP) immunoreactivity and mRNA expression in the duck gastrointestinal tract. Cell Tissue Res 2002, 308:347-359.

22. Sundby F, Frandsen EK, Thomsen J, Kristiansen K, Brunfeldt K: Crystallization and amino acid sequence of duck glucagon. FEBS letters 1972, 26:289-293.

23. Markussen J, Frandsen E, Heding LG, Sundby F: Turkey glucagon: crystallization, amino acid composition and immunology. Hormone Metab Res 1972, 4:360-363

24. Hasegawa S, Terazono K, Nata K, Takada T, Yamamoto H, Okamoto H: Nucleotide sequence determination of chicken glucagon precursor cDNA: Chicken preproglucagon does not contain glucagon-like peptide II. FEBS letters 1990, 264:117-120.

25. McFarlin DR, Lehn DA, Moran SM, MacDonald MJ, Epstein ML: Sequence of a cDNA encoding chicken vasoactive intestinal peptide (VIP). Gene 1995, 154:211-213.

26. MCRory JE, Parker RL, Sherwood NM: Expression and alternative processing of a chicken gene encoding both growth hormonereleasing hormone and pituitary adenylate cyclase-activating polypeptide. DNA Cell Biol 1997, 16:95-102.

27. Irwin DM, Zhang T: Evolution of the vertebrate glucose-dependent insulinotropic polypeptide (GIP) gene. Comp Biochem Physiol D Genome Proteo 2006, 1:385-395.

28. Wang Y, Conlon JM: Neuroendocrine peptides (NPY, GRP, VIP somatostatin) from the brain and stomach of the alligator. Peptides 1993, 14:573-579.

29. Lance V, Hamilton JW, Rouse JB, Kimmel JR, Pollock HG: Isolation and characterization of reptilian insulin, glucagon, and pancreatic polypeptide: complete amino acid sequence of alligator (Alligator mississippiensis) insulin and pancreatic polypeptide. Gen/ Comp Endocrinol 1984, 55:112-124.

30. Chen YE, Drucker DJ: Tissue-specific Expression of Unique mRNAs That Encode Proglucagon-derived Peptides or Exendin 4in the Lizard. J Biol Chem 1997, 272:4108-4115.

31. Valiante S, Prisco M, Capaldo A, Zambrano I, De Falco M, Andreuccetti P, Laforgia V, Varano L: Molecular characterization and gene expression of the pituitary adenylate cyclase-activating polypeptide (PACAP) in the lizard brain. Brain Res 2007, 1127:66-75.

32. Valiante S, Prisco M, De Falco M, Sellitti A, Zambrano I, Sciarrillo R, Capaldo A, Gay F, Andreuccetti P, Laforgia V: Distribution and Molecular Evolution of the Neuropeptide Pituitary Adenylate Cyclase-Activating Polypeptide (PACAP) and its Receptors in the Lizard Podarcis sicula (Squamata, Lacertidae). J Mol Neurosci 2009

33. Alexandre D, Vaudry H, Jegou S, Anouar Y: Structure and distribution of the mRNAs encoding pituitary adenylate cyclase-activating polypeptide and growth hormone-releasing hormone-like peptide in the frog, Rana ridibunda. J Comp Neurol 2000, 421:234-246.

34. Chartrel N, Wang Y, Fournier A, Vaudry H, Conlon JM: Frog vasoactive intestinal polypeptide and galanin: primary structures and effects on pituitary adenylate cyclase. Endocrinology 1995, 136:3079-3086.

35. Pollock HG, Kimmel JR: Chicken glucagon. Isolation and amino acid sequence studies. J Biol Chem 1975, 250:9377-9380.

36. Hu Z, Lelievre V, Tam J, Cheng JW, Fuenzalida G, Zhou X, Waschek JA: Molecular cloning of growth hormone-releasing hormone/pituitary adenylyl cyclase-activating polypeptide in the frog Xenopus laevis: brain distribution and regulation after castration. Endocrinology 2000 141:3366-3376

37. Lee LT, Siu FK, Tam JK, Lau IT, Wong AO, Lin MC, Vaudry H, Chow BK: Discovery of growth hormone-releasing hormones and receptors in nonmammalian vertebrates. Proc Natl Acad Sci USA 2007, 104:2133-2138.

38. Irwin DM, Satkunarajah M, Wen $Y$, Brubaker PL, Pederson RA, Wheeler MB: The Xenopus proglucagon gene encodes novel GLP-1-like peptides with insulinotropic properties. Proc Natl Acad Sci USA 1997, 94:7915-7920

39. Thwaites DT, Young J, Thorndyke MC, Dimaline R: The isolation and chemical characterization of a novel vasoactive intestinal peptide- related peptide from a teleost fish, the cod, Gadus morhua. Biochim Biophys Acta 1989, 999:217-220.

40. Xu M, Volkoff H: Molecular characterization of ghrelin and gastrinreleasing peptide in Atlantic cod (Gadus morhua): cloning, localization, developmental profile and role in food intake regulation. Gen Comp Endocrinol 2009, 160:250-258.

41. Uesaka T, Yano K, Yamasaki M, Ando M: Somatostatin-, Vasoactive Intestinal Peptide-, and Granulin-like Peptides Isolated from Intestinal Extracts of Goldfish, Carassius auratus. Gen Comp Endocrinol 1995 99:298-306

42. Matsuda K, Takei Y, Katoh J, Shioda S, Arimura A, Uchiyama M: Isolation and structural characterization of pituitary adenylate cyclase activating polypeptide (PACAP)-like peptide from the brain of a teleost, stargazer, Uranoscopus japonicus. Peptides 1997, 18:723-727.

43. Andrews PC, Ronner P: Isolation and structures of glucagon and glucagon-like peptide from catfish pancreas. J Biol Chem 1985, 260:3910-3914.

44. Small BC, Nonneman D: Sequence and expression of a cDNA encoding both pituitary adenylate cyclase activating polypeptide and growth hormone-releasing hormone-like peptide in channel catfish (Ictalurus punctatus). Gen Comp Endocrinol 2001, 122:354-363.

45. Tse DL, Pang RT, Wong AO, Chan SM, Vaudry H, Chow BK: Identification of a potential receptor for both peptide histidine isoleucine and peptide histidine valine. Endocrinology 2002, 143:1327-1336

46. KrueckI SL, Fradinger EA, Sherwood NM: Developmental changes in the expression of growth hormone-releasing hormone and pituitary adenylate cyclase-activating polypeptide in zebrafish. J Comp Neuro 2003, 455:396-405.

47. Wang $Y$, Wong $A O, G e W$ : Cloning, regulation of messenger ribonucleic acid expression, and function of a new isoform of pituitary adenylate cyclase-activating polypeptide in the zebrafish ovary. Endocrinology 2003, 144:4799-4810.

48. Zhou $\mathrm{L}$, Irwin DM: Fish proglucagon genes have differing coding potential. Comp Biochem Physiol B Biochem Mol Biol 2004, 137:255-264.

49. Taylor JS, Braasch I, Frickey T, Meyer A, Peer Y Van de: Genome duplication, a trait shared by 22000 species of ray finned fish. Genome Res 2003, 13:382-390.

50. Steinke D, Salzburger W, Braasch I, Meyer A: Many genes in fish have species-specific asymmetric rates of molecular evolution. BMC genomics 2006, 7:20

51. Meyer A, Peer $Y$ Van de: From $2 R$ to $3 R$ : evidence for a fish-specific genome duplication (FSGD). Bioessays 2005, 27:937-945.

52. Irwin DM, Huner O, Youson JH: Lamprey proglucagon and the origin of glucagon-like peptides. Mol Biol Evol 1999, 16:1548-1557.

53. Bourgault S, Vaudry D, Segalas-Milazzo I, Guilhaudis L, Couvineau A, Laburthe M, Vaudry H, Fournier A: Molecular and conformational determinants of pituitary adenylate cyclase-activating polypeptide (PACAP) for activation of the PAC1 receptor. J Med Chem 2009, 52:3308-3316.

54. Wray V, Nokihara K, Naruse S: Solution structure comparison of the VIP/ PACAP family of peptides by NMR spectroscopy. Ann N Y Acad Sci 1998, 865:37-44.

55. Gourlet $P$, Woussen-Colle MC, Robberecht $P$, de Neef $P$, Cauvin $A$, Vandermeers-Piret MC, Vandermeers A, Christophe J: Structural requirements for the binding of the pituitary adenylate-cyclaseactivating peptide to receptors and adenylate-cyclase activation in pancreatic and neuronal membranes. FEBS 1991, 195:535-541.

56. Gallwitz B, Witt M, Paetzold G, Morys-Wortmann C, Zimmermann B, Eckart K, Folsch UR, Schmidt WE: Structure/activity characterization of glucagon-like peptide-1. FEBS 1994, 225:1151-1156.

57. Roch GJ, Wu S, Sherwood NM: Hormones and receptors in fish: do duplicates matter? Gen Comp Endocrino/ 2009, 161:3-12.

58. Pfam Database [http://pfam.sanger.ac.uk]

59. Janssen T, Husson SJ, Lindemans M, Mertens I, Rademakers S, Ver Donck K, Geysen J, Jansen G, Schoofs L: Functional characterization of three G protein-coupled receptors for pigment dispersing factors in Caenorhabditis elegans. J Biol Chem 2008, 283:15241-15249.

60. Mertens I, Vandingenen A, Johnson EC, Shafer OT, Li W, Trigg JS, De Loof A, Schoofs L, Taghert PH: PDF receptor signaling in Drosophila contributes to both circadian and geotactic behaviors. Neuron 2005, 48:213-219.

61. Compagen [http://www.compagen.org] 
62. Gwee PC, Tay BH, Brenner S, Venkatesh B: Characterization of the neurohypophysial hormone gene loci in elephant shark and the Japanese lamprey: origin of the vertebrate neurohypophysial hormone genes. BMC Evol Biol 2009, 9:47.

63. de Jong-Brink M, ter Maat A, Tensen CP: NPY in invertebrates: molecular answers to altered functions during evolution. Peptides 2001, 22:309-315.

64. Garczynski SF, Crim JW, Brown MR: Characterization of neuropeptide F and its receptor from the African malaria mosquito, Anopheles gambiae. Peptides 2005, 26:99-107.

65. Larhammar D, Salaneck E: The NPY Family of Peptides in Immune Disorders, Inflammation, Angiogenesis and Cancer. Basel/Switzerland: Birkhäuser Verlag; 2005.

66. Hewes RS, Taghert PH: Neuropeptides and neuropeptide receptors in the Drosophila melanogaster genome. Genome Res 2001, 11:1126-1142.

67. Hernadi L, Hiripi L, Gyori J, Szabo H, Vehovszky A: The terrestrial snail, Helix pomatia, adapts to environmental conditions by the modulation of central arousal. Acta Biol Hung 2008, 59(Suppl):47-53.

68. Hashimoto $H$, Shintani N, Baba A: Higher brain functions of PACAP and a homologous Drosophila memory gene amnesiac: insights from knockouts and mutants. Biochim Biophys Res Comm 2002, 297:427-431.

69. Lerner EA, luga AO, Reddy VB: Maxadilan, a PAC1 receptor agonist from sand flies. Peptides 2007, 28:1651-1654.

70. Kandel E, Abel T: Neuropeptides, adenylyl cyclase, and memory storage. Science 1995, 268:825-826

71. Tatsuno I, Uchida D, Tanaka T, Saeki N, Hirai A, Saito Y, Moro O, Tajima M: Maxadilan specifically interacts with PAC1 receptor, which is a dominant form of PACAP/VIP family receptors in cultured rat cortical neurons. Brain Res 2001, 889:138-148.

72. Pereira P, Reddy VB, Kounga K, Bello Y, Lerner E: Maxadilan activates PAC1 receptors expressed in Xenopus laevis xelanophores. Pigment Cell Res 2002, 15:461-466.

73. Shemesh R, Toporik A, Levine Z, Hecht I, Rotman G, Wool A, Dahary D, Gofer E, Kliger Y, Soffer MA, et al:: Discovery and validation of novel peptide agonists for G-protein-coupled receptors. J Biol Chem 2008, 283:34643-34649

74. Hoare SR: Mechanisms of peptide and nonpeptide ligand binding to Class B G-protein-coupled receptors. Drug Discov Today 2005, 10:417-427.

75. Perry SJ, Junger S, Kohout TA, Hoare SR, Struthers RS, Grigoriadis DE, Maki RA: Distinct conformations of the corticotropin releasing factor type 1 receptor adopted following agonist and antagonist binding are differentially regulated. J Biol Chem 2005, 280:11560-11568.

76. Nicole $P$, Lins L, Rouyer-Fessard C, Drouot C, Fulcrand P, Thomas A, Couvineau A, Martinez J, Brasseur R, Laburthe M: Identification of key residues for interaction of vasoactive intestinal peptide with human VPAC1 and VPAC2 receptors and development of a highly selective VPAC1 receptor agonist. Alanine scanning and molecular modeling of the peptide. J Biol Chem 2000, 275:24003-24012.

77. Solano RM, Langer I, Perret J, Vertongen $P$, Juarranz MG, Robberecht $P$, Waelbroeck M: Two basic residues of the h-VPAC1 receptor second transmembrane helix are essential for ligand binding and signal transduction. J Biol Chem 2001, 276:1084-1088.

78. Unson CG, Macdonald D, Ray K, Durrah TL, Merrifield RB: Position 9 replacement analogs of glucagon uncouple biological activity and receptor binding. J Biol Chem 1991, 266:2763-2766.

79. Thornton JW, Need E, Crews D: Resurrecting the ancestral steroid receptor: ancient origin of estrogen signaling. Science 2003, 301:1714-1717.

80. Bridgham JT, Carroll SM, Thornton JW: Evolution of hormone-receptor complexity by molecular exploitation. Science 2006, 312:97-101.

81. Ohno S: Evolution by gene duplication. Berlin, New York: SpringerVerlag; 1970.

82. Holland PW, Garcia-Fernandez J, Williams NA, Sidow A: Gene duplications and the origins of vertebrate development. Dev Supp/ 1994:125-133.

83. Wu S, Roch GJ, Cervini LA, Rivier JE, Sherwood NM: Newly-identified receptors for peptide histidine-isoleucine and $\mathrm{GHRH}$-like peptide in zebrafish help to elucidate the mammalian secretin superfamily. J Mol Endocrinol 2008, 41:343-366.

84. Clynen E, De Loof A, Schoofs L: New insights into the evolution of the GRF superfamily based on sequence similarity between the locust APRPs and human GRF. Gen Comp Endocrinol 2004, 139:173-178.
85. Lindemans M, Liu F, Janssen T, Husson SJ, Mertens I, Gade G, Schoofs L: Adipokinetic hormone signaling through the gonadotropin-releasing hormone receptor modulates egg-laying in Caenorhabditis elegans. Proc Natl Acad Sci USA 2009, 106:1642-1647.

86. Park $Y$, Kim YJ, Adams ME: Identification of $G$ protein-coupled receptors for Drosophila PRXamide peptides, CCAP, corazonin, and AKH supports a theory of ligand-receptor coevolution. Proc Natl Acad Sci USA 2002, 99:11423-11428.

87. UniProt Database [http://www.expasy.org/tools/blast/]

88. Eddy SR: A probabilistic model of local sequence alignment that simplifies statistical significance estimation. PLoS Comput Biol 2008, 4:e1000069

89. Thompson JD, Gibson TJ, Plewniak F, Jeanmougin F, Higgins DG: The CLUSTAL_X windows interface: flexible strategies for multiple sequence alignment aided by quality analysis tools. Nucleic Acids Res 1997, 25:4876-4882

90. GeneDoc [http://www.psc.edu/biomed/genedoc

91. Ronquist F, Huelsenbeck JP: MrBayes 3: Bayesian phylogenetic inference under mixed models. Bioinformatics 2003, 19:1572-1574.

92. Lartillot N, Philippe $\mathrm{H}$ : A Bayesian mixture model for across-site heterogeneities in the amino-acid replacement process. Mol Biol Evol 2004, 21:1095-1109.

93. Fugu genome [http://fugu.nimr.mrc.ac.uk/

94. Ensembl Genome browser [http://www.ensembl.org]

95. NCBI MapViewer [http://www.ncbi.nlm.nih.gov/mapview/]

96. Giribet $\mathrm{G}$ : Relationships among metazoan phyla as inferred from $18 \mathrm{~S}$ rRNA sequence data: a methodological approach. Exs 2002:85-101.

97. Gerhart J, Lowe C, Kirschner M: Hemichordates and the origin of chordates. Curr Opin Genet Dev 2005, 15:461-467.

98. Delsuc F, Brinkmann H, Chourrout D, Philippe H: Tunicates and not cephalochordates are the closest living relatives of vertebrates. Nature 2006, 439:965-968.

99. PhyML [http://www.atgc-montpellier.fr/phyml/]

100. Takeda J, Seino Y, Tanaka K, Fukumoto H, Kayano T, Takahashi H, Mitani T, Kurono M, Suzuki T, Tobe T, et al: Sequence of an intestinal cDNA encoding human gastric inhibitory polypeptide precursor. Proc Natl Acad Sci USA 1987, 84:7005-7008

101. Moody AJ, Thim L, Valverde I: The isolation and sequencing of human gastric inhibitory peptide (GIP). FEBS letters 1984, 172:142-148.

102. Orskov C, Bersani M, Johnsen AH, Hojrup P, Holst JJ: Complete sequences of glucagon-like peptide- 1 from human and pig small intestine. J Biol Chem 1989, 264:12826-12829.

103. Drucker DJ, Asa S: Glucagon gene expression in vertebrate brain. J Biol Chem 1988, 263:13475-13478.

104. Yiangou Y, Di Marzo V, Spokes RA, Panico M, Morris HR, Bloom SR: Isolation, characterization, and pharmacological actions of peptide histidine valine 42, a novel prepro-vasoactive intestinal peptidederived peptide. J Biol Chem 1987, 262:14010-14013.

105. Linder S, Barkhem T, Norberg A, Persson H, Schalling M, Hokfelt T, Magnusson G: Structure and expression of the gene encoding the vasoactive intestinal peptide precursor. Proc Natl Acad Sci USA 1987 84:605-609.

106. Guillemin R, Brazeau P, Bohlen P, Esch F, Ling N, Wehrenberg WB: Growth hormone-releasing factor from a human pancreatic tumor that caused acromegaly. Science 1982, 218:585-587.

107. Mayo KE, Vale W, Rivier J, Rosenfeld MG, Evans RM: Expression-cloning and sequence of a CDNA encoding human growth hormone-releasing factor. Nature 1983, 306:86-88.

108. Kimura C, Ohkubo S, Ogi K, Hosoya M, Itoh Y, Onda H, Miyata A, Jiang L, Dahl RR, Stibbs HH, et al:: A novel peptide which stimulates adenylate cyclase: molecular cloning and characterization of the ovine and human cDNAs. Biochem Biophys Res Comm 1990, 166:81-89.

109. Whitmore TE, Holloway JL, Lofton-Day CE, Maurer MF, Chen L, Quinton TJ, Vincent JB, Scherer SW, Lok S: Human secretin (SCT): gene structure, chromosome location, and distribution of mRNA. Cytogenet Cell Genetics 2000, 90:47-52.

110. Wang Y, Li J, Wang CY, Kwok AH, Leung FC: Identification of the endogenous ligands for chicken growth hormone-releasing hormone (GHRH) receptor: evidence for a separate gene encoding GHRH in submammalian vertebrates. Endocrinology 2007, 148:2405-2416.

111. Nilsson A, Carlquist M, Jornvall H, Mutt V: Isolation and characterization of chicken secretin. FEBS 1980, 112:383-388 
112. Nilsson A: Structure of the vasoactive intestinal octacosapeptide from chicken intestine. The amino acid sequence. FEBS letters 1975 60:322-326

113. You S, Silsby JL, Farris J, Foster DN, el Halawani ME: Tissue-specific alternative splicing of turkey preprovasoactive intestinal peptide messenger ribonucleic acid, its regulation, and correlation with prolactin secretion. Endocrinology 1995, 136:2602-2610.

114. Pollock HG, Hamilton JW, Rouse JB, Ebner KE, Rawitch AB: Isolation of peptide hormones from the pancreas of the bullfrog (Rana catesbeiana). Amino acid sequences of pancreatic polypeptide, oxyntomodulin, and two glucagon-like peptides. J Biol Chem 1988, 263:9746-9751.

115. Yuen TTH, Mok PY, Chow BKC: Molecular cloning of a cDNA encoding proglucagon from goldfish, Carassius auratus. Fish Physiol Biochem 1997, V17:223-230.

116. McRory JE, Parker DB, Ngamvongchon S, Sherwood NM: Sequence and expression of CDNA for pituitary adenylate cyclase activating polypeptide (PACAP) and growth hormone-releasing hormone (GHRH)-like peptide in catfish. Mol Cell Endocrinol 1995, 108:169-177.

117. Fradinger EA, Sherwood NM: Characterization of the gene encoding both growth hormone-releasing hormone (GRF) and pituitary adenylate cyclase-activating polypeptide (PACAP) in the zebrafish. $\mathrm{Mol}$ Cell Endocrinol 2000, 165:211-219.

118. Argenton F, Zecchin E, Bortolussi M: Early appearance of pancreatic hormone-expressing cells in the zebrafish embryo. Mech Dev 1999, 87:217-221.

119. Parker DB, Coe IR, Dixon GH, Sherwood NM: Two salmon neuropeptides encoded by one brain CDNA are structurally related to members of the glucagon superfamily. FEBS 1993, 215:439-448.

120. Valiante S, Prisco M, Ricchiari L, Laforgia V, Varano L, Andreuccetti P: Distribution of PACAP in the brain of the cartilaginous fish torpedo marmorata. Ann N Y Acad Sci 2006, 1070:591-596.

121. Matsuda K, Itoh Y, Yoshida T, Shioda S, Arimura A, Uchiyama M: The localization of pituitary adenylate cyclase-activating polypeptide (PACAP)-like immunoreactivity in the hypothalamo-pituitary region of an elasmobranch, stingray, Dasyatis akajei. Peptides 1998, 19:1263-1267

122. Berks BC, Marshall CJ, Carne A, Galloway SM, Cutfield JF: Isolation and structural characterization of insulin and glucagon from the holocephalan species Callorhynchus milii (elephantfish). Biochem $J$ 1989, 263:261-266.

123. Conlon JM, Bondareva V, Rusakov Y, Plisetskaya EM, Mynarcik DC, Whittaker J: Characterization of insulin, glucagon, and somatostatin from the river lamprey, Lampetra fluviatilis. Gen Comp Endocrinol 1995, 100:96-105.

124. Conlon JM, Nielsen PF, Youson JH: Primary structures of glucagon and glucagon-like peptide isolated from the intestine of the parasitic phase lamprey Petromyzon marinus. Gen Comp Endocrinol 1993, 91:96-104.

125. Pestarino M: Immunocytochemical Localization of Glucagon-Related Peptides in the Cerebral Ganglion of the Protochordate Ascidian, Styela-Plicata. J Neuroendocrinol 1990, 2:641-645.

126. Fritsch HA, Van Noorden S, Pearse AG: Gastro-intestinal and neurohormonal peptides in the alimentary tract and cerebral complex of Ciona intestinalis (Ascidiaceae). Cell Tiss Res 1982, 223:369-402.

127. Sherwood NM, Adams BA, Tello JA: Endocrinology of protochordates. Can J Zool 2005, 83:225-255.

128. Pestarino M: Occurrence of different secretin-like cells in the digestive tract of the ascidian Styela plicata (Urochordata, Ascidiacea). Cell Tiss Res 1982, 226:231-235

129. Pestarino M: Localization of peptide histidine isoleucine-like immunoreactivity in the gut of the ascidian, Styela plicata. Anim Biol 1993, 2:91-95.

130. Reinecke M: Immunohistochemical Localization of Polypeptide Hormones in Endocrine-Cells of the Digestive-Tract of BranchiostomaLanceolatum. Cell Tiss Res 1981, 219:445-456.

131. Dimaline R: Vasoactive Intestinal Peptide. Edited by: Susanne Holmgren. London, New York: Chapman and Hall; 1989.

132. Foster N, Lee DL: Vasoactive intestinal polypeptide-like and peptide histidine isoleucine-like proteins excreted/secreted by Nippostrongylus brasiliensis, Nematodirus battus and Ascaridia galli. Parasitology 1996, 113(Pt 3):287-292
133. Andries JC, Belemtougri G, Tramu G: Immunohistochemical identification of growth hormone-releasing factor-like material in the nervous system of an insect, Aeshna cyanea (Odonata). Neuropeptides 1984, 4:519-528.

134. Andries JCBG, Tramu G: Multiple peptide immunoreactivities in the nervous system of Aeschna cyanea (Insecta, Odonata). An immunohistochemical study using antisera to cholecystokinin octapeptide, somatoliberin, vasoactive intestinal peptide, motilin and proctolin. Histochemistry 1991, 96:139-148.

135. El-Salhy M, Abou-el-Ela R, Falkmer S, Grimelius L, Wilander E: Immunohistochemical evidence of gastro-entero-pancreatic neurohormonal peptides of vertebrate type in the nervous system of the larva of a dipteran insect, the hoverfly, Eristalis aeneus. Reg Pept 1980, 1:187-204

136. El-Salhy M, Falkmer S, Kramer KJ, Speirs RD: Immunohistochemical investigations of neuropeptides in the brain, corpora cardiaca, and corpora allata of an adult lepidopteran insect, Manduca sexta (L). Cell Tiss Res 1983, 232:295-317.

137. Fujita T, Yui R, Iwanaga T, Nishiitsutsujiuwo J, Endo Y, Yanaihara N: Evolutionary Aspects of Brain-Gut Peptides - an Immunohistochemical Study. Peptides 1981, 2:123-131.

138. Kuramoto $H$, Yui R, Iwanaga T, Fujita T, Yanaihara N: PHI-like immunoreactivity in the nervous system of the cockroach (insect) and Aplysia (mollusc) with special reference to its relationship to VIP-like immunoreactivity. Arch Histol Jpn 1985, 48:427-433.

139. Osborne NN, Patel S, Dockray G: Immunohistochemical demonstration of peptides, serotonin and dopamine-beta-hydroxylase-like material in the nervous system of the leech Hirudo medicinalis. Histochemistry 1982, 75:573-583.

140. Sundler F, Hakanson R, Alumets J, Walles B: Neuronal localization of pancreatic polypeptide (PP) and vasoactive intestinal peptide (VIP) immunoreactivity in the earthworm (Lumbricus terrestris). Brain Res Bull 1977, 2:61-65

141. Reglodi D, Lengvari I, Szelier M, Vigh S, Arimura A: Distribution of PACAPlike immunoreactivity in the nervous system of oligochaeta. Peptides 2000, 21:183-188.

142. Dhainaut-Courtois N, Dubois MP, Tramu G, Masson M: Occurrence and coexistence in Nereis diversicolor O.F. Muller (Annelida Polychaeta) of substances immunologically related to vertebrate neuropeptides. Cell Tiss Res 1985, 242:97-108.

143. Kaufmann W, Kerschbaum HH, Hauser-Kronberger C, Hacker GW, Hermann A: Distribution and seasonal variation of vasoactive intestinal (VIP)-like peptides in the nervous system of Helix pomatia. Brain Res 1995, 695:125-136.

144. Licata A, Ainis L, Martella S, Ricca MB, Licata P, Pergolizzi S, Calabro C, Zaccone G: Immunohistochemical localization of nNOS and VIP in the mantle integument of the mussel, Mytilus galloprovincialis. Acta Histochem 2003, 105:143-149.

145. Ottaviani E, Cossarizza A: Immunocytochemical evidence of vertebrate bioactive peptide-like molecules in the immuno cell types of the freshwater snail Planorbarius corneus (L.) (Gastropoda, Pulmonata). FEBS letters 1990, 267:250-252.

146. Ottaviani E, Franchini A, Fontanili P: The presence of immunoreactive vertebrate bioactive peptide substances in hemocytes of the freshwater snail Viviparus ater (Gastropoda, Prosobranchia). Cell Mol Neurobiol 1992, 12:455-462.

147. Gustafsson MKS: Immunocytochemical Demonstration of Neuropeptides and Serotonin in the Nervous-System of Adult Schistosoma-Mansoni. Parasitol Res 1987, 74:168-174.

doi: $10.1186 / 1471-2148-10-135$

Cite this article as: Cardoso et al., The serendipitous origin of chordate secretin peptide family members BMC Evolutionary Biology 2010, 10:135 